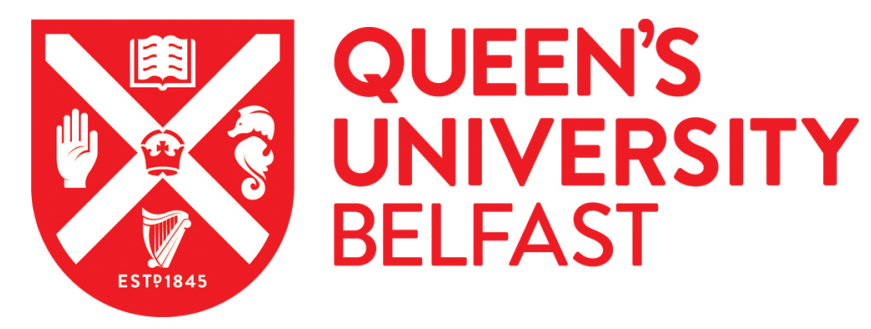

\title{
Identification and Characterization of Dual Inhibitors of the USP25/ 28 Deubiquitinating Enzyme Subfamily
}

Wrigley, J. D., Gavory, G., Simpson, I., Preston, M., Plant, H., Bradley, J., Goeppert, A. U., Rozycka, E., Davies, G., Walsh, J., Valentine, A., McClelland, K., Odrzywol, K. E., Renshaw, J., Boros, J., Tart, J., Leach, L., Nowak, T., Ward, R. A., ... Andrews, D. M. (2017). Identification and Characterization of Dual Inhibitors of the USP25/ 28 Deubiquitinating Enzyme Subfamily. ACS Chemical Biology. https://doi.org/10.1021/acschembio.7b00334

Published in:

ACS Chemical Biology

Document Version:

Peer reviewed version

Queen's University Belfast - Research Portal:

Link to publication record in Queen's University Belfast Research Portal

Publisher rights

(c) 2017 ACS. This work is made available online in accordance with the publisher's policies. Please refer to any applicable terms of use of the publisher.

\section{General rights}

Copyright for the publications made accessible via the Queen's University Belfast Research Portal is retained by the author(s) and / or other copyright owners and it is a condition of accessing these publications that users recognise and abide by the legal requirements associated with these rights.

Take down policy

The Research Portal is Queen's institutional repository that provides access to Queen's research output. Every effort has been made to ensure that content in the Research Portal does not infringe any person's rights, or applicable UK laws. If you discover content in the Research Portal that you believe breaches copyright or violates any law, please contact openaccess@qub.ac.uk. 
Title:

Identification and characterisation of dual inhibitors of the USP25/28 Deubiquitinating enzyme subfamily.

\section{Authors:}

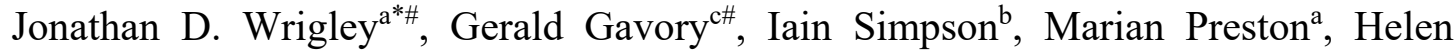
Plant $^{\mathrm{a}}$, Jenna Bradley ${ }^{\mathrm{a}}$, Anne U. Goeppert ${ }^{\mathrm{a}}$, Ewelina Rozycka ${ }^{\mathrm{c}}$, Gareth Davies ${ }^{\mathrm{a}}$, Jarrod Walsh $^{\mathrm{a}}$, Andrea Valentine ${ }^{\mathrm{c}}$, Keeva McClelland ${ }^{\mathrm{c}}, \mathrm{Krzysztofa}$ Ewa Odrzywol ${ }^{\mathrm{c}}$, Jonathan Renshaw $^{\mathrm{a}}$, Joanna Boros ${ }^{\mathrm{a}}$, Jonathan Tart ${ }^{\mathrm{a}}$, Lindsey Leach ${ }^{\mathrm{a}}$, Thorsten Nowak ${ }^{\mathrm{b}}$, Richard A. Ward ${ }^{\mathrm{b}}$, Timothy Harrison ${ }^{\mathrm{c}} \&$ David M Andrews ${ }^{\mathrm{b}}$ \#Joint Co-authors

Address:

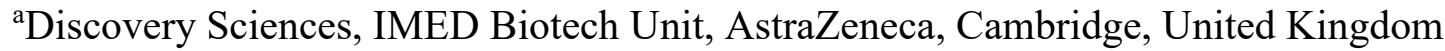
boncology, IMED Biotech Unit, AstraZeneca, Cambridge, United Kingdom

${ }^{c}$ Almac Discovery Ltd, Centre for Precision Therapeutics, 97 Lisburn Road, BT9 7AE, United Kingdom.

\section{*Corresponding Author}

Dr. Jonathan Wrigley

IMED Biotech Unit, AstraZeneca, Unit 310 - Darwin Building, Cambridge Science Park, Milton Rd, Cambridge CB4 0FZ

Tel: (+44) 01625235830

Fax: (+44) 01625519749

Email: jonathan.wrigley@astrazeneca.com

\section{Word Count: 8002}

(Abstract, Body Text, Methods, References, Figure legends) 


\section{ABSTRACT}

The Ubiquitin Proteasome System is widely postulated to be a new and important field of drug discovery for the future, with the Ubiquitin Specific Proteases (USP) representing one of the more attractive target classes within the area. Many USPs have been linked to critical axes for therapeutic intervention, and the finding that USP28 is required for c-Myc stability suggests that USP28 inhibition may represent a novel approach to target this so far undruggable oncogene. Here we describe the discovery of the first reported inhibitors of USP28, which we demonstrate are able to bind to and inhibit USP28, and whilst displaying a dual activity against the closest homologue USP25, these inhibitors show a high degree of selectivity over other deubiquitinases (DUBs). The utility of these compounds as valuable probes to investigate and further explore cellular DUB biology is highlighted by the demonstration of target engagement against both USP25 and USP28 in cells. Furthermore, we demonstrate that these inhibitors are able to elicit modulation of both the total levels and the half-life of the c-Myc oncoprotein in cells, and also induce apoptosis and loss of cell viability in a range of cancer cell lines. We however observed a narrow therapeutic index compared to a panel of tissue-matched normal. Thus, it is hoped that these probes and data presented herein will further advance our understanding of the biology and tractability of DUBs as potential future therapeutic targets. 


\section{GRAPHICAL TABLE OF CONTENTS ENTRY}

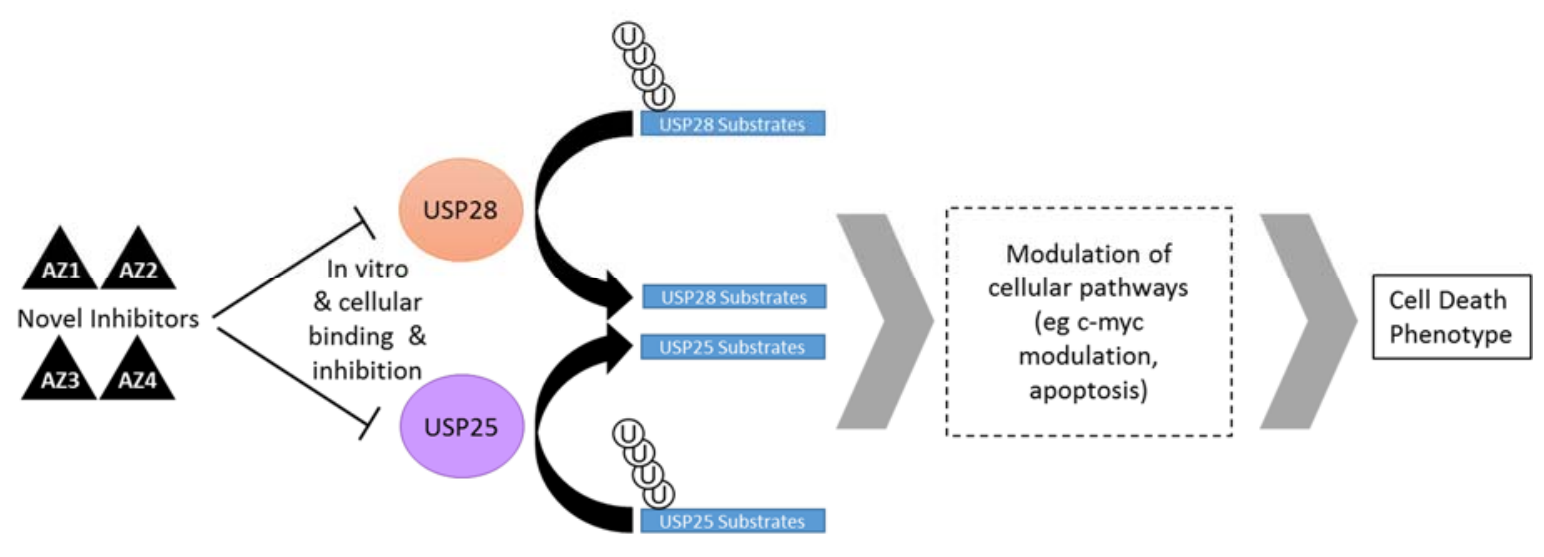




\section{INTRODUCTION}

Whilst considerable progress has been made in enabling the efficient discovery and development of therapeutic agents for a wide range of disease areas, many challenges still remain, including the high attrition rates of molecules in development and a reliance on historically tractable target classes, such as kinases ${ }^{1}$. For these reasons, significant effort has been devoted towards identifying and generating hit molecules directed against new target classes that may represent novel axes for therapeutic intervention. The growing disease linkage and essentiality to many cellular processes, make the Ubiquitin Proteasome System (UPS) an attractive target class for the discovery of new therapeutic entities ${ }^{2,3}$.

The UPS represents the major eukaryotic pathway for selective proteolysis of intracellular proteins, through the concerted action of E1, E2 \& E3 ubiquitin ligases which elicit protein regulation by the addition of the 76 amino-acid Ubiquitin (Ub) molecule in chains of varying length and linkage complexity ${ }^{4}$. Notably, the ability to generate and attach a wide variety of different $\mathrm{Ub}$ chains to proteins through attachment at specific amino acid residues via different linkages, equips the cell with a highly sophisticated means of directing proteins towards a variety of cellular outcomes. One such example is the attachment of four or more Lysine 48-linked Ubiquitin moieties to a protein which generally targets it for proteasomal degradation. The ubiquitination process is reversible and an additional layer of regulation is afforded to the cell through the action of deubiquitinating enzymes (DUBs), which cleave $\mathrm{Ub}$ from the target and are thereby able to reverse the process, precluding for instance proteasomal destruction.

DUBs comprise a large family of mostly cysteine proteases, split into sub-families of which the Ubiquitin Specific Protease family (USPs) is the largest ${ }^{5}$. Through cleavage of the isopeptide bond between the C-terminal Gly 76 of $\mathrm{Ub}$ and the $\varepsilon$-amino group of the lysine residue of the target protein, the enzymes modulate a wide range of cellular axes, with growing linkages to cancer-associated pathways ${ }^{6-8}$. It is therefore anticipated that, building on the success of the proteasome inhibitor Bortezimib (Velcade) in multiple myeloma ${ }^{9}$, both the DUBs in general ${ }^{2}$ and USPs in particular may represent a rich source of novel therapeutic agents. 
Despite a growing number of linkages between DUBs and key disease loci, drug discovery in this area remains in its infancy, and to date has been focussed on a small number of enzymes ${ }^{10-12}$. Furthermore, whilst the recent identification of several inhibitors of USP $1^{13}, \mathrm{USP}^{14,15}{ }^{15} \mathrm{USP} 8^{16}, \mathrm{USP} 9 \mathrm{x}^{17}$ and USP $14^{18}$ yields promise, the general challenges in identifying leads with a clear mechanism of action, phenotypic effect and profile suitable for progression towards a clinical candidate remain to be overcome $^{19,20}$. Thus, a crucial step in the development of this potential target class is the identification and characterisation of hit molecules against novel DUBs, to further increase our knowledge of both chemical tractability and biological potential for modulation of key cellular pathways.

One such potential opportunity arose following the discovery by Popov and colleagues in 2007 that USP28 is able to bind to and preclude proteasomal degradation of c-Myc through an interaction with the Fbw7 $\alpha$ ubiquitin E3 ligase $^{21}$. Although the c-Myc proto-oncogene was discovered over 30 years ago, from a drug discovery perspective it remains a challenging, yet attractive target ${ }^{22,} 23$. Further relevance of USP28 as a potential therapeutic target comes from the growing association between expression of USP28 and Fbw7 and a range of tumour types ${ }^{24-27}$. However, c-Myc regulation is highly complex ${ }^{28}$, and furthermore additional reports have suggested that the USP28 / c-Myc relationship is not straight forward, with an apparent dual regulation, resulting in either elevation or downregulation of Fbw7 substrates depending on the degree of USP2 $81 \operatorname{loss}^{29}$. Whilst further characterisation of c-Myc regulation is thus needed, the prospect of indirectly targeting and modulating c-Myc levels by targeting USP28 prompted us to initiate a screening campaign for the de novo identification of hits against this target of potentially high clinical relevance.

Here we describe the use of a high throughput screening (HTS) approach to successfully identify the first reported USP28 inhibitors, which have been characterised in a range of biochemical and cellular assays. We demonstrate not only that these compounds inhibit USP28 in vitro, but also confirm by two independent methods, that they directly and productively bind to USP28. We also show that whilst these inhibitors possess a high degree of in vitro selectivity over most DUB family 
members they possess equipotent activity against the closest related homologue, USP25. Initial cellular characterisation supported the in vitro data demonstrating that the compounds engage both USP28 and USP25. These inhibitors were then used as chemical probes to start investigating the biology of USP28. These studies demonstrated direct modulation of USP28 substrates in cells, including total c-Myc levels in cells. This effect was achieved through modulation of the half-life of c-Myc via a proteasome-dependent mechanism. Further cellular characterisation shows that these inhibitors cause induction of apoptosis and affect cell viability across a range of cancer cell lines but with a minimal window compared to a panel of normal cell lines. Together these data highlight the utility of these probe molecules in the further characterisation of both this cellular pathway and wider DUB biology, which will be required for the generation of novel therapeutics against this target class. 


\section{RESULTS \& DISCUSSION}

As outlined above, the identification of USP28 inhibitors would add considerable value to the growing Ubiquitin drug discovery field, through both enabling better characterisation of the cellular DUB activity and also providing start points for the development of therapeutic molecules. In order to achieve this, we employed a high throughput screening strategy using purified recombinant USP28 enzyme and a fluorogenic substrate consisting of Ubiquitin derivatised at the C-terminus with Rhodamine-110 (Ub-Rh110) ${ }^{30}$. A comprehensive assay development was performed, as described in the supporting information, including analysis and optimisation of the assay time course, $\mathrm{Km}$ determination, effect of reducing agents, $Z^{\prime}$ analysis ${ }^{31}$ and validation with a broad-spectrum inhibitor (Supporting information, Figure S1a-d). Following completion of the assay development and validation phases, a high throughput screening (HTS) campaign was run using a directed library of approximately 40,000 compounds. Around half of these compounds were selected as a representative set of the AstraZeneca full compound collection, favouring scaffolds with a range of near-neighbours for follow-up testing. The other half consisted of compounds which have shown activity against one or more protease assays within AstraZeneca.

The HTS campaign yielded a primary hit rate of approximately $5.3 \%$, and primary hits were subsequently analysed in a "ratio-test" assay 32 format to assess specificity (Figure S1e-f). A "ratio test" was performed to assess specificity of the hits, by screening the compounds on two occasions. The first occasion utilised the assay conditions determined for primary screening whilst the second employed 10-fold higher levels of enzyme, but tested over a 10-fold shorter timescale. For compounds that specifically inhibit the enzyme (i.e. non-spurious, non-promiscuous), the inhibition profile and $\mathrm{IC}_{50}$ value should be identical under both conditions. However, compounds that inhibit via a non-specific mechanism (e.g. aggregator or reactive compounds), are expected to display a shift in the $\mathrm{IC}_{50}$ values between the two conditions. The data clearly showed both a population of likely "specific" inhibitors (whose profiles do not alter, $\mathrm{n}=15$ ), and a second population of 10-fold shifted (and therefore likely non-specific, false positive) hits $(\mathrm{n}=27)$ (supplementary information Figure S1f). 
By combining data from the "ratio-test" assay with chemo-informatic analysis (solubility, redox activity) of the USP28 primary screening data we selected a subset of 42 compounds for further profiling.

As part of the validation phase by titration, a series of benzylaminoethanols represented by AZ1, AZ2 and AZ4, were identified which exhibited $\mathrm{IC}_{50}$ values of 0.7, 1.1 and $2.0 \mu \mathrm{M}$ respectively (Table 1). Interestingly, our studies also revealed a structurally related but significantly less active inhibitor namely AZ3 with an $\mathrm{IC}_{50}$ value of $59.6 \mu \mathrm{M}$ (Table 1). Since identification of these compounds, more physiologically relevant substrates have been brought into use, such as Di-Ubiquitin ${ }^{33}$, the isopeptide linked Ubiquitin-tetramethyrhodamine (Ub-TMR) substrate and the tetra-ubiquitin chain Tetra-Ub. For comparative purposes, additional studies were subsequently performed with the latter two of these substrates and the compounds exhibited similar $\mathrm{IC}_{50}$ values with these more physiologically relevant substrates (Table 1). Further characterisation of this class of compounds was then performed, commencing with binding validation using orthogonal biophysical techniques.

For these binding studies, two independent biophysical techniques were utilised, the first of which was Isothermal Titration Calorimetry (ITC). This label free methodology directly measures the heat of binding for the interaction that occurs when a ligand binds to a target protein, and can be used to confirm ligand binding, calculate the equilibrium dissociation constant $\left(\mathrm{K}_{\mathrm{d}}\right)$, and stoichiometry of the interaction. These parameters are additionally useful to characterize the binding interaction and to demonstrate the functional integrity of the enzyme. Under the conditions of our experiments, $\mathrm{K}_{d}$ values of $0.2,0.9 \& 2.7 \mu \mathrm{M}$ were derived for AZ1, AZ2 \& AZ4 respectively (Figure 1a-c; Table 1), whilst the less active close analogue AZ3 failed to produce a measurable $K_{d}$ value. These values are consistent with the biochemical activity data described previously. In addition, corresponding stoichiometry values of $0.6,0.7 \& 0.8$ were derived for AZ1, AZ2 \& AZ4 respectively (Fig. 1a-c) in line with a non-spurious and specific mode of binding, hence supporting our initial observations from the "ratio test" experiments. For comparison, two compounds determined by the "ratio test" as potentially acting via alternative mechanisms were also tested and produced noisy and difficult to interpret data (data not shown). The second approach taken to confirm binding of the 
compounds to USP28 utilised the NanoTemper Microscale Thermophoresis (MST) methodology, which produced comparable data. In this instance, $K_{d}$ values of 3.7, and $10.3 \mu \mathrm{M}$ were determined for AZ1 and AZ2 respectively (Supporting information Figure S2a-b and Table 1). In agreement with the ITC data AZ3 failed to produce a determinable result. The binding constants for the compounds were determined using the protein's intrinsic fluorescence. We believe this resulted in a less sensitive detection system than the fluorescently labeled version of the approach. This may in part account for the apparent discrepancy in $\mathrm{K}_{\mathrm{d}}$ estimates between MST and ITC. In contrast AZ4 generated a $\mathrm{K}_{\mathrm{d}}$ using the labeled protein which was in much closer agreement with the ITC result (3.6 vs $2.7 \mu \mathrm{M}$; Table 1). Despite $\mathrm{K}_{d}$ values being higher than the $\mathrm{IC}_{50}$ values obtained in the in vitro enzyme assay and the $\mathrm{K}_{\mathrm{d}}$ values from our ITC experiments further confirm target-ligand engagement. Taken together these data derived from two independent methodologies demonstrate AZ1, AZ2 and AZ4 interact with and bind to USP28 in a non-spurious and specific manner.

Building upon these studies and performing a high-dilution assay format, we also demonstrated that these inhibitors bind reversibly to the USP28 target. Briefly, in this assay USP28 was pre-incubated with 10 times the $\mathrm{IC}_{50}$ concentration of the inhibitor (where full inhibition is expected), followed by 100 -fold dilution. USP28 activity is then re-assessed and full restoration of the activity is expected upon re-equilibration in the case of a reversible binder as observed with the inhibitors AZ1-AZ4 (Supplementary information; Figure S5). This data is also consistent with the lack of any reactive functionality on these molecules. Iodoacetamide was used in these experiments as a non-specific alkylator and irreversible inhibitor of DUBs.

Following the reversibility studies, kinetic experiments were subsequently performed to characterise the mode of inhibition of USP2 8 using the most potent compound AZ1 as a representative example. In these studies, we assayed USP28 across a range of Tetra-Ub substrate concentrations in the presence of increasing concentrations of inhibitor. Lineweaver-Burk analysis revealed that AZ1 acts as a non-competitive inhibitor (Supporting information Figure S6). The apparent $K_{\mathrm{m}}$ value for Tetra-Ub was calculated as $8.6 \mu \mathrm{M}$ and the inhibitory constant for AZ1 derived from this analysis $\left(K_{\mathrm{i}}=1.5 \mu \mathrm{M}\right)$ was in excellent agreement with the $\mathrm{IC}_{50}$ value obtained previously $\left(\mathrm{IC}_{50}=0.7-1.0 \mu \mathrm{M}\right.$; Table 1$)$. 
With clear and robust inhibitory activity demonstrated against USP28, we next assessed the selectivity profiles of AZ1-AZ4 against representative USPs and DUBs. To this end, and as part of our internal validation process, AZ1-4 were routinely counter-screened against the USP2a protein. All compounds were found to be inactive against this particular DUB with $\mathrm{IC}_{50}$ values $>100 \mu \mathrm{M}$ (Table 1). AZ1-3 were subsequently profiled against an extended and commercially available panel of DUBs (Ubiquigent), which included 14 USPs (USPs1, 2, 4, 5, 7, 11, 15, 19, 20, 25, 28, 36, $45 \&$ CYLD), and 8 further DUBs comprising 4 UCHs (UCHL1, UCHL3, UCHL5 \& BAP1), 3 OTUs (OTUB2, OTUD6B, Cezanne) and 1 JAMM (AMSHLP). The data obtained in these Ub-Rho110-based assays (performed at $10 \mu \mathrm{M}$ fixed inhibitor concentration) demonstrated strong inhibition of both USP28 \& USP25 (>90\%), whilst no significant effect was observed against any of the other family members tested $(<10 \%$ inhibition; Fig. 2a). Our most potent inhibitor AZ1 was subsequently taken as a representative example and tested at a fixed concentration of $30 \mu \mathrm{M}$ (i.e. $>40$-fold $\mathrm{IC}_{50}$ USP28) against representative caspases and cathepsins. Under the conditions of these experiments, no off-target effects were observed against any of these cysteine proteases ( $<25 \%$ inhibition; Supporting information, Figure S7). Thus, under the conditions of these experiments, the compounds appear to be potent inhibitors of USP28 \& USP25 and highly selective over all other 20 DUBs included in this panel and over a selection of other non-related proteases. To the best of our knowledge these compounds represent the first validated inhibitors of either USP28 or USP25.

Based on these data, we further characterised the ability of the compounds to inhibit USP25 in vitro with follow-up titration studies for $\mathrm{IC}_{50}$ determination. Parallel doseresponse testing of $A Z 1,2, \& 3$ in purified enzyme assays demonstrated that all three compounds appear approximately equipotent against USP28 and USP25 (Fig 2b-e). In concordance with our previous studies, AZ3 was found to be only weakly active against USP25 with $30 \%$ inhibition at $10 \mu \mathrm{M}$ and an $\mathrm{IC}_{50}$ value of $26.4 \mu \mathrm{M}$. This dual activity can be explained by the high degree of homology ( $>50 \%$ nucleotide and amino acid identity \& highly conserved exon-intron boundaries) between USP28 and its structurally closest analogue, USP $25^{34}$, and is indicative that, whilst identification of compounds with broad selectivity across the DUB family is achievable, obtaining 
selectivity between the closest homologues may represent, in some circumstances, a significant challenge.

Following the extensive in vitro profiling described above, we next wanted to determine whether these inhibitors were able to directly engage USP28 in a cellular environment. To this aim, activity-based profiling studies were carried out using the Ubiquitin-vinyl sulfone substrate (Ub-VS) as molecular probe. Ub-VS is a potent and reactive inhibitor of DUBs and its covalent interaction with the enzyme can be detected by mobility shift in western blotting analysis. As shown in Figure 3a, increasing concentration of the inhibitors AZ1, AZ2 and AZ4 initially reduced and ultimately ablated, in a concentration dependant manner, the covalent labelling of USP 28 by Ub-VS. Densitometry analyses were subsequently performed and $\mathrm{EC}_{50}$ values of 5.3, 18.2 and $11.3 \mu \mathrm{M}$ were derived from these experiments for AZ1, AZ2 and AZ4 respectively. In contrast, AZ3 had no significant effect at either 60 or 100 $\mu \mathrm{M}$ (Fig. 3a). These data corroborate our previous biochemical and biophysical studies and unambiguously demonstrate direct evidence for target occupancy in cells.

In response to the observation of activity against USP25 in an in vitro enzyme assay, we next performed additional cellular target engagement assays to determine whether the inhibitors interacted with USP25 in a cellular context. These data clearly demonstrate that in parallel to interacting with USP28, AZ1, AZ2 \& AZ4 are also able to engage with USP25 with $\mathrm{EC}_{50}$ values of 3.3, 11.5 and $19.6 \mu \mathrm{M}$ respectively (Fig 3b.). In contrast, target engagement of less-closely related DUB family members such as USP7 and USP4 was not observed up to $60 \mu \mathrm{M}$, in line with the DUB screening panel data (Fig 3c.). The potency and selectivity profiles of AZ1, AZ2 and AZ4 combined with good physicochemical properties (Molecular Weight $<500, \operatorname{LogD}_{7.4}$ in the 2.7-3.5 range and good solubility (Table 1)), made them suitable molecular and functional probes for further cellular investigations.

Since the primary goal of our screening campaign was the identification of USP2 8 inhibitors, we next prioritised proof-of-concept cellular studies using these validated inhibitors, to probe the regulation of endogenous c-Myc protein levels by USP28 in the HCT116 colon carcinoma cell line. HCT116 was used as a model cell line for our initial mechanistic studies based on both the high USP28 expression and also 
precedence from the Popov et al. studies ${ }^{21}$ demonstrating regulation of c-Myc protein levels by USP28 using siRNA. Cells were treated with increasing concentrations of compounds and samples were collected after $3 \mathrm{hrs}$ for analysis. As shown in Figure $4 \mathrm{a}$, western blotting analyses indicate a rapid and concentration-dependant decrease in c-Myc total protein levels following treatment with AZ1 and AZ2. Complete reduction in c-Myc levels was observed in both cases at the highest concentrations tested. Importantly, the decrease in c-Myc levels could not be attributed to total protein degradation following compound treatment as evidenced by the steady state levels in the loading control $\beta$-actin or USP28. Similar studies performed with the less active structurally related compound AZ3 only showed an effect on c-Myc levels at the highest concentration of $100 \mu \mathrm{M}$ (and to a much lesser extent at $80 \mu \mathrm{M}$ ). No significant effect was detectable at $60 \mu \mathrm{M}$ or below (Fig. 4a). Together, the relative activity of the three compounds correlates well with their activity in the biochemical and target engagement assays described previously.

Furthermore, AZ1 and AZ2 were observed to induce apoptosis in a rapid and concentration-dependant manner as evidenced by the cleavage of full-length PARP into a smaller $(85 \mathrm{kDa})$ adduct (Fig. 4a). Interestingly, the concentration-dependent reduction in c-Myc levels was mirrored by a concomitant increase in PARP cleavage. Apoptosis induction was most pronounced following complete down-regulation of cMyc. Under the conditions of these experiments, no PARP cleavage or apoptosis was detected following treatment with AZ3 up to $100 \mu \mathrm{M}$ (Fig. 4a). Subsequently, we decided to extend our investigations beyond HCT116 cells and demonstrated that similar trends and effects were observed in multiple other cell lines including the colorectal adenocarcinoma SW480 and HT29 lines (Fig. S3a-b).

Next, a series of experiments were performed in an attempt to elucidate the mechanism responsible for the rapid decrease in c-Myc total protein levels following compound treatment. To determine whether the decrease in total c-Myc protein levels was mediated through the proteasome, HCT116 cells were pre-treated with both cycloheximide (CHX) and the proteasome inhibitor MG-132, followed by treatment with compound AZ1 or vehicle as a control. Samples were subsequently collected at various timepoints for western blot analysis probing for c-Myc levels. As shown in Fig. 4b, MG132 efficiently blocked the reduction in total c-Myc abundance resulting 
in steady state levels of the protein for up to $180 \mathrm{~min}$ (the longest timepoint investigated). Under the conditions of these experiments and following densitometry analysis, the half-life of c-Myc was determined to be $72 \mathrm{~min}$ in untreated cells whilst treatment with AZ1 significantly reduced this value by almost $50 \%$ to $40 \mathrm{~min}$. Together, these studies demonstrate that the observed reduction in total c-Myc protein levels is mediated by proteasomal degradation.

Flow cytometry analysis was then performed to assess the effect of the compounds over a longer time-period. The study demonstrated cell death induction in a dosedependent manner, as evidenced by the accumulation of a sub-G1 population (Supporting information; Figure S4). Based on these data, the anti-proliferative effect of these compounds was subsequently investigated. Briefly, cells were treated with increasing concentrations of the compounds (up to $100 \mu \mathrm{M}$ ) and cell viability was assessed after $72 \mathrm{hrs}$. In good agreement with the observed sub-G1 population accumulation, our data demonstrate a dose-dependent loss of cell viability with $\mathrm{EC}_{50}$ values of 18.0-20.0 $\mu \mathrm{M}$ range for AZ1 and AZ2 (Fig. 5a). Under the same conditions, AZ3 was approximately 3-fold less active exhibiting an $\mathrm{EC}_{50}$ value of $93.2 \mu \mathrm{M}$. Similar effects on viability were observed in the HT29 and SW480 cell lines (Fig. 5a; EC $_{50}$ values compiled in Supplementary Table 1). Altogether, these studies demonstrated that AZ1 and AZ2 inhibitors are able to induce both dose and time dependent cell cycle perturbations and cell death resulting in an anti-proliferative response.

In order to further characterise the potential therapeutic opportunity afforded by these compounds, their effect on cell viability was monitored across a broader range of tumour cell lines from different tissue of origins and also tissue-matched normal cells. In total, a representative panel of 29 cell lines was used in this study including 22 cancer cell lines and 7 tissue-matched normal cell lines. Proliferation assays were performed as described previously and the compiled dataset is shown in Fig. 5b \& compiled in Supplementary Table 1. Our data demonstrated that AZ1 and AZ2 were able to reduce cell viability across a range of cancer cell lines with $\mathrm{EC}_{50}$ values typically clustered around $20 \mu \mathrm{M}$. Further analysis however indicated that no significant differentiation in response was observed between tumour and normal cell types (Fig. 5b). A minimal window of 3-5-fold was still typically observed between 
the active compounds AZ1 and AZ2, and the less active analogue AZ3, in both the normal and cancer sets. We attempted to further optimise and develop these initial studies to improve this narrow therapeutic index. To this end, longer term viability assay (up to 7 days) and clonogenic assays (up to 12 days) were carried out but with little effect on the cancer to normal cell lines window. Similarly, changing the treatment modality in these assay formats to repeated or pulse treatments brought no further improvement (data not shown). We believe that this lack of selective killing results from the complexity of the pathways involved and potential redundancy between family members, such that the oncogenic effects of any specific gene amplifications, for example, are minimised. This hypothesis of a more complex scenario could be further investigated through the generation of a panel of genomeedited cell lines (e.g. CRISPR/Cas9-based), to characterise both the compounds and pathways in knockout models. Furthermore, it is hoped that further optimisation of these compounds may improve both potency and selectivity, which is likely to improve the therapeutic index.

The studies described herein report the identification and early characterisation of the first reported inhibitors of USP28 and USP25, which are able to bind to and inhibit both recombinant and endogenous enzymes. These inhibitors exhibit good biochemical potency and binding affinity as well as excellent selectivity profiles against a broader panel of DUBs. In cells, these compounds engage both targets and induce a dose-dependent reduction in the endogenous levels of a reported USP28 substrate c-Myc, which we showed is mediated by the proteasome. Further cellular profiling demonstrated that these compounds induce apoptosis and in turn exert an anti-proliferative effect in both cancer and normal cell lines, albeit with no significant window in response. Whilst the observed c-Myc modulation is consistent with previous reports of the action of USP $28^{21}$, we cannot exclude the possibility that the apoptotic and cell viability phenotypic effects are arising as a result of parallel inhibition of both USP25 and USP28. For example, it is plausible that whilst c-Mycdriven effects may result from USP28 inhibition, other phenotypic observations, such as the induction of PARP cleavage could result from an alternative action on USP25. Therefore, the potential for redundancy to occur within the DUB family, coupled with the challenge of obtaining selectivity between closely related family members (e.g. as 
previously reported between USP7 and USP47 ${ }^{35}$ ), represent key challenges to be considered in the generation of therapeutic inhibitors of USPs.

Given the limited number of quality, reversible inhibitors published to date, it is anticipated that these detailed studies and orthogonally validated probes will be of significant utility to the broad research community. Firstly, since these molecules represent the first reported inhibitors of both enzymes, they should enable further investigation of the cellular biology related to USP25 and USP28, as well as probing the selectivity and redundancy between these closely related DUBs. For example, proteomic analysis following treatment of cells with these inhibitors may help characterisation of both their action and in turn reveal the complexity and interplay of DUB activities.

Further development and optimisation of these scaffolds to improve both potency, and selectivity between USP25 and USP28, may not only aid such investigations, but may potentially improve the therapeutic index between activity in normal and cancer cells. Additionally, these probe compounds could act as seeds and provide templates for the development of inhibitors of USP28, USP25 and other members of this challenging target class. Indeed, our demonstration of the ability to identify broadly selective small molecules able to both bind to and inhibit USP targets in vitro and in cells, and the fact that the issues of selectivity and redundancy are likely to be target specific, provides encouragement that therapeutically relevant USP inhibitors can be developed in the future. 


\section{MATERIALS \& METHODS}

\section{Chemistry:}

Compounds AZ1-4 were prepared as described in the Supporting Information.

\section{Binding Assays - Isothermal Titration Calorimetry}

The USP28 protein and test compounds were dialysed in 40 mM HEPES ( $\mathrm{pH} 7.5), 150$ $\mathrm{mM} \mathrm{NaCl}$, in order to minimise heat effects due to buffer mismatch or ionisation. ITC experiments were carried out with $20 \mu \mathrm{M}$ USP28 protein, contained in the cell of a Microcal iTC200 instrument, titrated with $200 \mu \mathrm{M}$ test compound, contained in the instrument injection syringe. The interaction of USP28 with test compound was quantified using a Microcal ITC 200 (GE healthcare). The titration data were recorded at $25^{\circ} \mathrm{C}$ in $40 \mathrm{mM}$ HEPES pH 7.5, $150 \mathrm{mM} \mathrm{NaCl}, 2 \%$ DMSO. Aliquots of $200 \mu \mathrm{M}$ ligand stocks were added to $20 \mu \mathrm{M}$ USP2 8 in multiple $2 \mu \mathrm{L}$ intervals. Data was analysed using non-linear least squares regression using Microcal Origin software (GE healthcare).

\section{USP Selectivity Assessment}

The selectivity of compounds across the DUB family was analysed through testing in the DUBProfiler panel at Ubiquigent (www.ubiquigent.com). This involved inclusion of test compounds at a concentration of $10 \mu \mathrm{M}$ in a range of Ub-Rho110 in vitro enzyme assays. Enzyme assays were generated and run for the following DUB-family members: 14 USPs (USPs1, 2, 4, 5, 7, 11, 15, 19, 20, 25, 28, 36, 45 \& CYLD), 4 UCHs (UCHL1, UCHL3, UCHL5 \& BAP1), 3 OTUs (OTUB2, OTUD6B, Cezanne) and 1 JAMM (AMSH-LP). Data generated is displayed as a percentage inhibition of total enzyme activity for each enzyme. Dose response testing against USP28 and USP25 was performed in the same way, testing compounds in the range of 100$0.03 \mu \mathrm{M}$. Selectivity of AZ1 against cysteine proteases including caspases 1/2/4/5/8 and cathepsins $\mathrm{H} / \mathrm{L} / \mathrm{S}$ was tested at a fixed screening concentration of $30 \mu \mathrm{M}$ and data reported as \% of enzyme activity relative to DMSO control (Reaction Biology).

\section{Cell Assays}

In order to assess cellular activity of the compounds, HCT116 cells were treated with USP28 inhibitor compounds for a period of $3 \mathrm{hrs}$. Following this incubation, cells were harvested, lysed and subjected to Western Blot analysis. Samples were probed for c-Myc protein levels and also probed for $\beta$-actin levels, as a loading control. In 
order to determine the half-life of c-Myc in cells, HCT116 cells were treated for $3 \mathrm{hr}$ with USP28 inhibitors in the presence of cycloheximide $(100 \mu \mathrm{g} / \mathrm{ml})$ to block nascent protein synthesis. Thus any alteration in c-Myc levels would be indicative of changes in degradation as opposed to protein synthesis. Following compound treatment, cells were harvested and lysed prior to Western blot analysis

\section{Cells lines and culture conditions}

All cell lines were obtained from the American Type Culture Collection (ATCC), and were both authenticated by STR profiling (Promega) and shown to be mycoplasma-free through external (Cell Check 9 Plus; IDEXX BioResearch) or internal testing with the MycoAlert mycoplasma detection (Lonza; LT07-318). For growth, cells were maintained at $37^{\circ} \mathrm{C}$ in a humidified atmosphere with $5 \% \mathrm{CO} 2$. HCT116 and HT29 were cultured in McCoys 5A supplemented with 10\% (v/v) FBS, 1\% (v/v) Penicillin/streptoMycin, 1\% (v/v) L-Glutamine. DU145, LNCAP, PC3, PNT2, A549 and OVCAR8 were cultured in RPMI supplemented with 10\% (v/v) FBS, 1\% (v/v) Penicillin/streptoMycin, 1\% (v/v) L-Glutamine. InMyo Fib were cultured in Smooth Muscle Cell Basal Medium (Lonza). NL20 were cultured in F-12, Ham Nutrient Mixture supplemented with 4\% (v/v) FBS, 1\% (v/v) Penicillin/streptoMycin, 1\% (v/v) L-Glutamine, 1\% (v/v) NEAA, $5 \mu \mathrm{g} / \mathrm{ml}$ of Insulin (Sigma Aldrich), $0.05 \mu \mathrm{g} / \mathrm{ml}$ of transferrin, $0.5 \mu \mathrm{g} / \mathrm{ml}$ of hydrocortisone (Sigma Aldrich) and $0.05 \mu \mathrm{g} / \mathrm{ml}$ of EGF (Sigma Aldrich). U87MG, U251 and A431 were cultured in DMEM supplemented with 10\% (v/v) FBS, 1\% (v/v) Penicillin/ streptoMycin, 1\% (v/v) L-Glutamine. HMEC-1 were cultured in MCDB-131 supplemented with 10\% (v/v) FBS, 1\% (v/v) Penicillin/streptoMycin, 1\% (v/v) LGlutamine, EGF $1 \mathrm{ng} / \mathrm{ml}$. Medium and supplements were purchased from Life Technologies except were indicated.

\section{Reagents for cellular characterisation}

The USP28 inhibitors (AZ1, AZ2, AZ3 and AZ4) were prepared as $100 \mathrm{mM}$ DMSO stocks for cell culture experiments. Cycloheximide was purchased from Calbiochem and used at a final concentration of $100 \mu \mathrm{g} / \mathrm{mL}$. MG132 and Propidium Iodide (PI) were both obtained from Sigma-Aldrich and used at a final concentration of $20 \mu \mathrm{M}$ and $10 \mu \mathrm{g} / \mathrm{mL}$ respectively. RNaseA was purchased from Qiagen and used at a final concentration of $250 \mu \mathrm{g} / \mathrm{mL}$. CellTitre-Glo (cell viability assay) was purchased from 
Promega. Ubiquitin-Vinyl Sulfone (Ub-VS) was purchased from Boston Biochem and used at a final concentration of $32 \mu \mathrm{g} / \mathrm{ml}$.

\section{Western blotting and antibody sources}

Cells were lysed in radioimmuno-precipitation (RIPA) buffer containing $50 \mathrm{mM}$ Tris $\mathrm{HCl}$ (pH 7.6), $150 \mathrm{mM} \mathrm{NaCl}, 1 \mathrm{mM}$ EDTA, 1\% NP40, 0.25\% Na-deoxycholate and supplemented with a phosphatase (PhosSTOP, Roche) and protease inhibitor cocktail tablet (cOmplete Mini, Roche). Antibodies were obtained from AbCam; anti-USP28 (Ab110744; 1:1000 dilution), anti-USP25 (ab187156; 1:1000), BD Bioscience;; antiUSP28 (A300-898A; 1:1000), Cell Signaling; anti-c-Myc (5605; 1:1000) and antiPARP (9542; 1:1000), anti-USP28 (4217, 1:1000), Santa Cruz; anti- $\beta$-actin (A5316; 1:5000), HRP conjugated anti-rabbit (A0545 1:5000) and HRP conjugated anti-mouse (A9917; 1:5000).

\section{Target engagement assay}

HCT116 cells were treated with USP28 inhibitors for 2 hr. Following incubation, cells were harvested in TE lysis buffer containing $50 \mathrm{mM}$ Tris (pH7.4), $150 \mathrm{mM} \mathrm{NaCl}, 5$ $\mathrm{mM} \mathrm{MgCl2,} 0.5$ mM EDTA, 0.5\% NP40, 10\% Glycerol, 2 mM DTT and clarified cell lysates $(40 \mu \mathrm{g})$ incubated with Ubiquitin-vinyl Sulfone in assay buffer containing 50 mM Tris (pH7.6), $5 \mathrm{mM} \mathrm{MgCl}$, $250 \mathrm{mM}$ Sucrose, $0.5 \mathrm{mM}$ EDTA, $2 \mathrm{mM}$ DTT for 1 hr on ice. The reaction was terminated by the addition of LDS sample buffer (Life Technologies) and heated to $70^{\circ} \mathrm{C}$. Samples were then analysed by western blotting.

\section{Proliferation Assays}

Cells were typically seeded in 96 well plate format (typically 4000-6000 cells/well) and treated after $24 \mathrm{hrs}$ with increasing concentration of compound from 0 to $100 \mu \mathrm{M}$ in $1 / 2 \log$ unit increments. Cell viability was assessed after $72 \mathrm{hrs}$ by CellTiter-Glo ${ }^{\circledR}$ as recommended by the manufacturer's instructions (Promega). Analysis and EC 50 values were derived using GraphPadPrism. 


\section{ACKNOWLEDGEMENTS}

The authors wish to thank K. Hudson, K. Eckersley, D. O’Neill, N. Davies, M. Wappett and G. McCathie for valued input into this work. Thanks also go to J. Brown $\&$ S. Armour for enabling the selectivity profiling at Ubiquigent.

\section{Supporting Information Available:}

This material is available free of charge via the Internet. 


\section{REFERENCES}

[1] Paul, S. M., Mytelka, D. S., Dunwiddie, C. T., Persinger, C. C., Munos, B. H., Lindborg, S. R., and Schacht, A. L. (2010) How to improve R\&D productivity: the pharmaceutical industry's grand challenge, Nat Rev Drug Discov 9, 203-214.

[2] Cohen, P., and Tcherpakov, M. (2010) Will the ubiquitin system furnish as many drug targets as protein kinases?, Cell 143, 686-693.

[3] Nalepa, G., Rolfe, M., and Harper, J. W. (2006) Drug discovery in the ubiquitinproteasome system, Nat Rev Drug Discov 5, 596-613.

[4] Komander, D. (2009) The emerging complexity of protein ubiquitination, Biochem Soc Trans 37, 937-953.

[5] Nijman, S. M., Luna-Vargas, M. P., Velds, A., Brummelkamp, T. R., Dirac, A. M., Sixma, T. K., and Bernards, R. (2005) A genomic and functional inventory of deubiquitinating enzymes, Cell 123, 773-786.

[6] Komander, D., Clague, M. J., and Urbe, S. (2009) Breaking the chains: structure and function of the deubiquitinases, Nat Rev Mol Cell Biol 10, 550-563.

[7] Reyes-Turcu, F. E., Ventii, K. H., and Wilkinson, K. D. (2009) Regulation and cellular roles of ubiquitin-specific deubiquitinating enzymes, Annu Rev Biochem 78, 363-397.

[8] Sacco, J. J., Coulson, J. M., Clague, M. J., and Urbe, S. (2010) Emerging roles of deubiquitinases in cancer-associated pathways, IUBMB Life 62, 140-157.

[9] Adams, J., and M., K. (2004) Development of the Proteasome Inhibitor Velcade TM (Bortezomib), Cancer Investigation 22, 304-311.

[10] Nicholson, B., Marblestone, J. G., Butt, T. R., and Mattern, M. R. (2007) Deubiquitinating enzymes as novel anticancer targets, Future Oncology 3 , 191-197.

[11] Daviet, L., and Colland, F. (2008) Targeting ubiquitin specific proteases for drug discovery, Biochimie 90, 270-283.

[12] Harrigan, J. A., Jacq, X., Martin, N. M., and Jackson, S. P. (2017) Deubiquitylating enzymes and drug discovery: emerging opportunities, Nat Rev Drug Discov.

[13] Liang, Q., Dexheimer, T. S., Zhang, P., Rosenthal, A. S., Villamil, M. A., You, C., Zhang, Q., Chen, J., Ott, C. A., Sun, H., Luci, D. K., Yuan, B., Simeonov, A., Jadhav, A., Xiao, H., Wang, Y., Maloney, D. J., and Zhuang, Z. (2014) A selective USP1-UAF1 inhibitor links deubiquitination to DNA damage responses, Nat Chem Biol 10, 298-304.

[14] Colland, F., Formstecher, E., Jacq, X., Reverdy, C., Planquette, C., Conrath, S., Trouplin, V., Bianchi, J., Aushev, V. N., Camonis, J., Calabrese, A., BorgCapra, C., Sippl, W., Collura, V., Boissy, G., Rain, J. C., Guedat, P., Delansorne, R., and Daviet, L. (2009) Small-molecule inhibitor of USP7/HAUSP ubiquitin protease stabilizes and activates p53 in cells, $\mathrm{Mol}$ Cancer Ther 8, 2286-2295.

[15] Reverdy, C., Conrath, S., Lopez, R., Planquette, C., Atmanene, C., Collura, V., Harpon, J., Battaglia, V., Vivat, V., Sippl, W., and Colland, F. (2012)

Discovery of specific inhibitors of human USP7/HAUSP deubiquitinating enzyme, Chem Biol 19, 467-477.

[16] Colombo, M., Vallese, S., Peretto, I., Jacq, X., Rain, J. C., Colland, F., and Guedat, P. (2010) Synthesis and biological evaluation of 9-охо-9H- 
indeno[1,2-b]pyrazine-2,3-dicarbonitrile analogues as potential inhibitors of deubiquitinating enzymes, ChemMedChem 5, 552-558.

[17] Kapuria, V., Peterson, L. F., Fang, D., Bornmann, W. G., Talpaz, M., and Donato, N. J. (2010) Deubiquitinase inhibition by small-molecule WP1130 triggers aggresome formation and tumor cell apoptosis, Cancer Res 70, 92659276.

[18] Lee, B. H., Lee, M. J., Park, S., Oh, D. C., Elsasser, S., Chen, P. C., Gartner, C., Dimova, N., Hanna, J., Gygi, S. P., Wilson, S. M., King, R. W., and Finley, D. (2010) Enhancement of proteasome activity by a small-molecule inhibitor of USP14, Nature 467, 179-184.

[19] Wrigley, J. D., Eckersley, K., Hardern, I. M., Millard, L., Walters, M., Peters, S. W., Mott, R., Nowak, T., Ward, R. A., Simpson, P. B., and Hudson, K. (2011) Enzymatic characterisation of USP7 deubiquitinating activity and inhibition, Cell Biochem Biophys 60, 99-111.

[20] Sheridan, C. (2015) Drug makers target ubiquitin proteasome pathway anew, Nature Biotechnology 33, 1115-1117.

[21] Popov, N., Wanzel, M., Madiredjo, M., Zhang, D., Beijersbergen, R., Bernards, R., Moll, R., Elledge, S. J., and Eilers, M. (2007) The ubiquitin-specific protease USP28 is required for MYC stability, Nat Cell Biol 9, 765-774.

[22] Meyer, N., and Penn, L. Z. (2008) Reflecting on 25 years with MYC, Nature Reviews Cancer 8, 977-990.

[23] A., A., J.I., J., and Henriksson, M. A. (2010) MYC in oncogenesis and as a target for cancer therapies, Advances in Cancer Research 107, 163-224.

[24] Shah, S. P., Morin, R. D., Khattra, J., Prentice, L., Pugh, T., Burleigh, A., Delaney, A., Gelmon, K., Guliany, R., Senz, J., Steidl, C., Holt, R. A., Jones, S., Sun, M., Leung, G., Moore, R., Severson, T., Taylor, G. A., Teschendorff, A. E., Tse, K., Turashvili, G., Varhol, R., Warren, R. L., Watson, P., Zhao, Y., Caldas, C., Huntsman, D., Hirst, M., Marra, M. A., and Aparicio, S. (2009) Mutational evolution in a lobular breast tumour profiled at single nucleotide resolution, Nature 461, 809-813.

[25] Diefenbacher, M. E., Popov, N., Blake, S. M., Schulein-Volk, C., Nye, E., Spencer-Dene, B., Jaenicke, L. A., Eilers, M., and Behrens, A. (2014) The deubiquitinase USP28 controls intestinal homeostasis and promotes colorectal cancer, J Clin Invest 124, 3407-3418.

[26] Zhang, L., Xu, B., Qiang, Y., Huang, H., Wang, C., Li, D., and Qian, J. (2015) Overexpression of deubiquitinating enzyme USP28 promoted non-small cell lung cancer growth, J Cell Mol Med 19, 799-805.

[27] Welcker, M., and Clurman, B. E. (2008) FBW7 ubiquitin ligase: a tumour suppressor at the crossroads of cell division, growth and differentiation, Nat Rev Cancer 8, 83-93.

[28] Vervoorts, J., Luscher-Firzlaff, J., and Luscher, B. (2006) The ins and outs of MYC regulation by posttranslational mechanisms, J Biol Chem 281, 3472534729.

[29] Schulein-Volk, C., Wolf, E., Zhu, J., Xu, W., Taranets, L., Hellmann, A., Janicke, L. A., Diefenbacher, M. E., Behrens, A., Eilers, M., and Popov, N. (2014) Dual regulation of Fbw7 function and oncogenic transformation by Usp28, Cell Rep 9, 1099-1109.

[30] Hassiepen, U., Eidhoff, U., Meder, G., Bulber, J. F., Hein, A., Bodendorf, U., Lorthiois, E., and Martoglio, B. (2007) A sensitive fluorescence intensity 
assay for deubiquitinating proteases using ubiquitin-rhodamine 110 -glycine as substrate, Anal Biochem 371, 201-207.

[31] Zhang, J. (1999) A simple statistical parameter for use in evaluation and validation of High Throughput Screening Assays, Journal of Biomolecular Screening 4, 67-73.

[32] Habig, M., Blechschmidt, A., Dressler, S., Hess, B., Patel, V., Billich, A., Ostermeier, C., Beer, D., and Klumpp, M. (2009) Efficient elimination of nonstoichiometric enzyme inhibitors from HTS hit lists, J Biomol Screen 14, 679-689.

[33] Ritorto, M. S., Ewan, R., Perez-Oliva, A. B., Knebel, A., Buhrlage, S. J., Wightman, M., Kelly, S. M., Wood, N. T., Virdee, S., Gray, N. S., Morrice, N. A., Alessi, D. R., and Trost, M. (2014) Screening of DUB activity and specificity by MALDI-TOF mass spectrometry, Nat Commun 5, 4763.

[34] Valero, R., Marfany, G., Gonzalez-Angalo, O., Gonzalez-Gonzalez, G., Puelles, L., and Gonzalez-Duarte, R. (1999) USP25, a Novel Gene Encoding a Deubiquitinating Enzyme, Is Located in the Gene-Poor Region 21q11.2, Genomics 62, 395-405.

[35] Altun, M., Kramer, H. B., Willems, L. I., McDermott, J. L., Leach, C. A., Goldenberg, S. J., Kumar, K. G., Konietzny, R., Fischer, R., Kogan, E., Mackeen, M. M., McGouran, J., Khoronenkova, S. V., Parsons, J. L., Dianov, G. L., Nicholson, B., and Kessler, B. M. (2011) Activity-based chemical proteomics accelerates inhibitor development for deubiquitylating enzymes, Chem Biol 18, 1401-1412. 
Figures:

\begin{tabular}{|c|c|c|c|c|}
\hline Compound Number & AZ1 & $\mathbf{A Z 2}$ & AZ3 & AZ4 \\
\hline \multicolumn{5}{|l|}{ Structure } \\
\hline $\begin{array}{c}\mathrm{USP} 8 \mathrm{IC}_{50}(\mu \mathrm{M})- \\
\text { Ub-Rh110 assay }\end{array}$ & $\begin{array}{c}0.7 \\
(n=4)\end{array}$ & $\begin{array}{c}1.1 \\
(n=4)\end{array}$ & $\begin{array}{c}59.6 \\
(n=3)\end{array}$ & $\begin{array}{c}2.0 \\
(n=24)\end{array}$ \\
\hline $\begin{array}{c}\mathrm{USP} 28 \mathrm{IC}_{50}(\mu \mathrm{M})- \\
\mathrm{Ub}-\mathrm{TMR} \text { assay }\end{array}$ & $\begin{array}{c}1.0 \\
(n=3)\end{array}$ & $\begin{array}{c}0.9 \\
(n=3)\end{array}$ & $\begin{array}{c}68.4 \\
(\mathrm{n}=3)\end{array}$ & $\begin{array}{c}2.1 \\
(\mathrm{n}=3)\end{array}$ \\
\hline 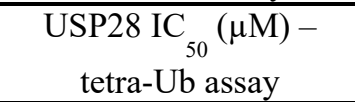 & $\begin{array}{c}0.8 \\
(n=4)\end{array}$ & $\begin{array}{c}1.3 \\
(\mathrm{n}=4)\end{array}$ & $\begin{array}{c}98.0 \\
(\mathrm{n}=4)\end{array}$ & $\begin{array}{c}1.5 \\
(n=4)\end{array}$ \\
\hline 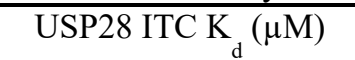 & 0.2 & 0.9 & $>100$ & 2.7 \\
\hline USP28 MST $\mathrm{K}_{d}(\mu \mathrm{M})$ & $\begin{array}{c}3.7 \\
(\mathrm{n}=2)\end{array}$ & $\begin{array}{c}10.3 \\
(\mathrm{n}=2)\end{array}$ & $\begin{array}{l}>100 \\
(n=2)\end{array}$ & $\begin{array}{c}3.6 \\
(\mathrm{n}=2)\end{array}$ \\
\hline $\begin{array}{c}\mathrm{USP}^{25} \mathrm{IC}_{50}(\mu \mathrm{M})- \\
\text { Ub-Rh110 assay }\end{array}$ & 0.62 & 0.88 & 52.53 & $\mathrm{Nd}$ \\
\hline $\begin{array}{c}\text { USP2a IC }_{50}(\mu \mathrm{M})- \\
\text { Ub-Rh110 assay }\end{array}$ & $\begin{array}{l}>100 \\
(n=6)\end{array}$ & $\begin{array}{l}>100 \\
(n=5)\end{array}$ & $>100$ & $>100$ \\
\hline Molecular Weight & 422 & 420 & 336 & 390 \\
\hline $\log \mathrm{D}$ & 3.3 & 3.5 & 2.2 & 2.7 \\
\hline $\begin{array}{l}\text { LLE USP28 enzyme } \\
\mathrm{pIC}_{50}-\operatorname{LogD}\end{array}$ & 2.8 & 2.5 & 2 & 3 \\
\hline Solubility at $\mathrm{pH}_{7.4}(\mu \mathrm{M})$ & 80 & 166 & 855 & 652 \\
\hline $\mathrm{pK}_{\mathrm{a}}$ & 8.9 & 8.9 & $\mathrm{Nd}$ & $\mathrm{Nd}$ \\
\hline Human plasma \%free & 3.7 & 4.1 & $\mathrm{Nd}$ & $\mathrm{Nd}$ \\
\hline
\end{tabular}

Table 1 Overall profiles of USP28/USP25 inhibitors.

The HTS hit finding approach found benzylic aminoethanols of the structural class represented by compounds AZ1-4. The in vitro profiles of AZ1, AZ2 and AZ4 show them to be active against the USP28 enzyme and to bind to USP28 by iso-thermal calorimetry (ITC) \& Microscale Thermophoresis (MST). They were also shown to be selective over USP2a. A fourth analogue (AZ3) was shown to be significantly less potent at inhibiting USP28 but retained selectivity over USP2a. The data shown in the table were generated from one experimental replicate, unless stated otherwise. 
Figure 1: Orthogonal hit validation and characterisation

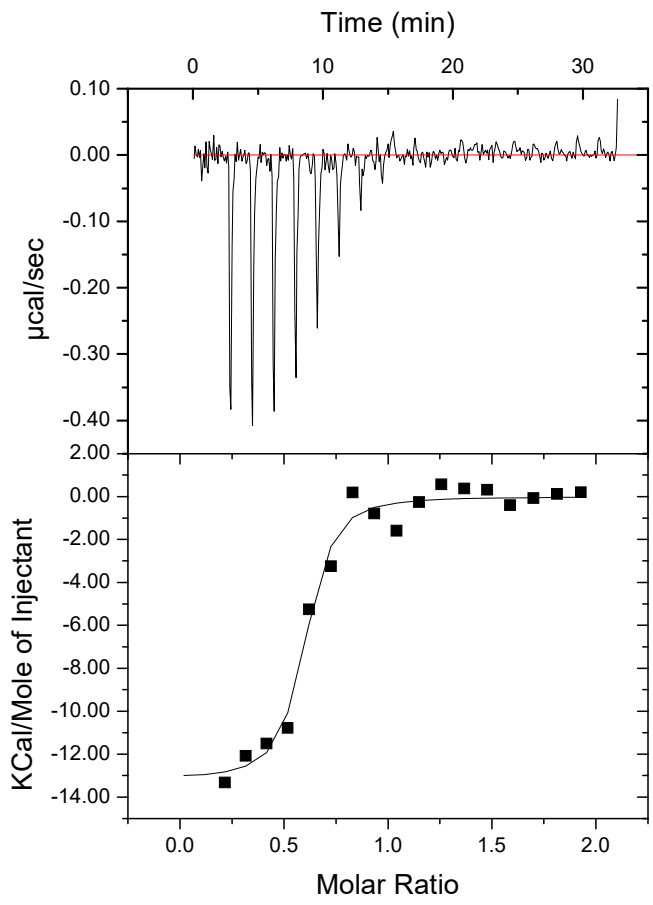

(a) Isothermal Calorimetry: AZ1

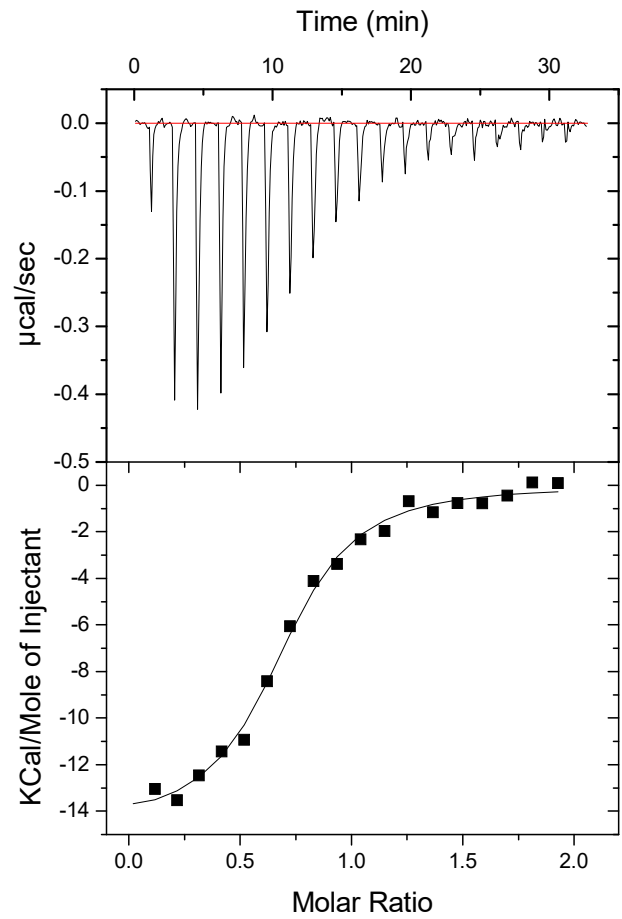

(b) Isothermal Calorimetry: AZ2 


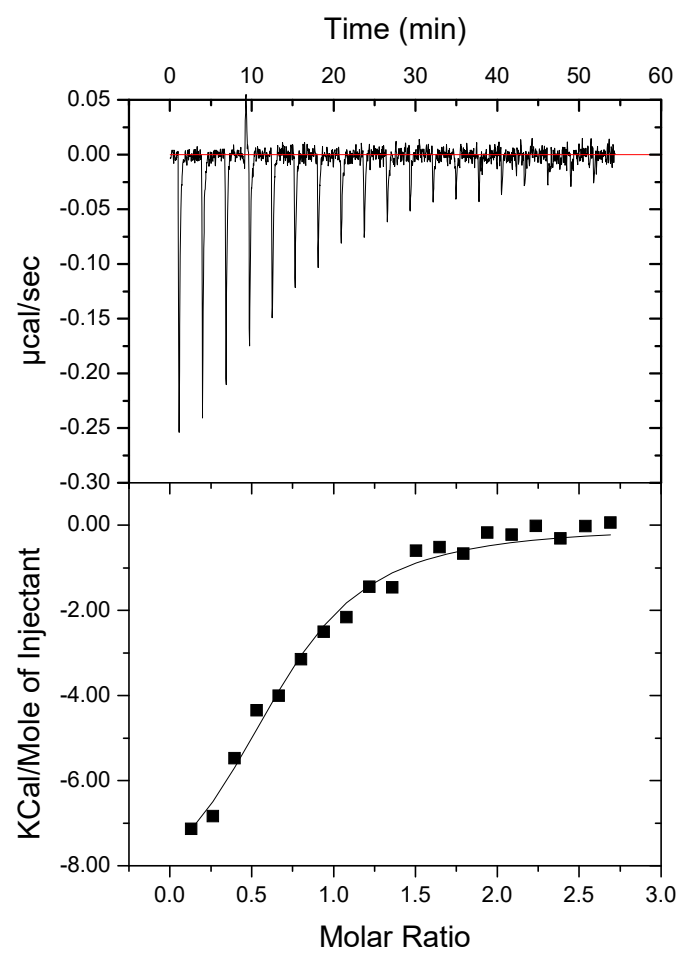

(c) Isothermal Calorimetry: AZ4

Figure 1 a-c: Iso-thermal titration calorimetry (ITC) data demonstrating AZ1, AZ2 \& AZ4 inhibitor binding to USP28. ITC ligand binding measurement confirmed inhibitor binding to USP28 and determined the affinity of the interaction. Data are shown for (a) AZ1, (b) AZ2 and (c) AZ4 binding to USP28. The less potent analogue, AZ3, failed to produce a measurable $K_{d}$ value. The data shown are representative data from a single experiment. The USP28 protein and test compound binding partners were dialysed in $40 \mathrm{mM}$ HEPES ( $\mathrm{pH} 7.5$ ), $150 \mathrm{mM} \mathrm{NaCl}$, in order to minimise heat effects due to buffer mismatch or ionisation. Data was analysed using nonlinear least squares regression using Microcal Origin software (GE Healthcare). 
Figure 2: Inhibitor Selectivity Profiling

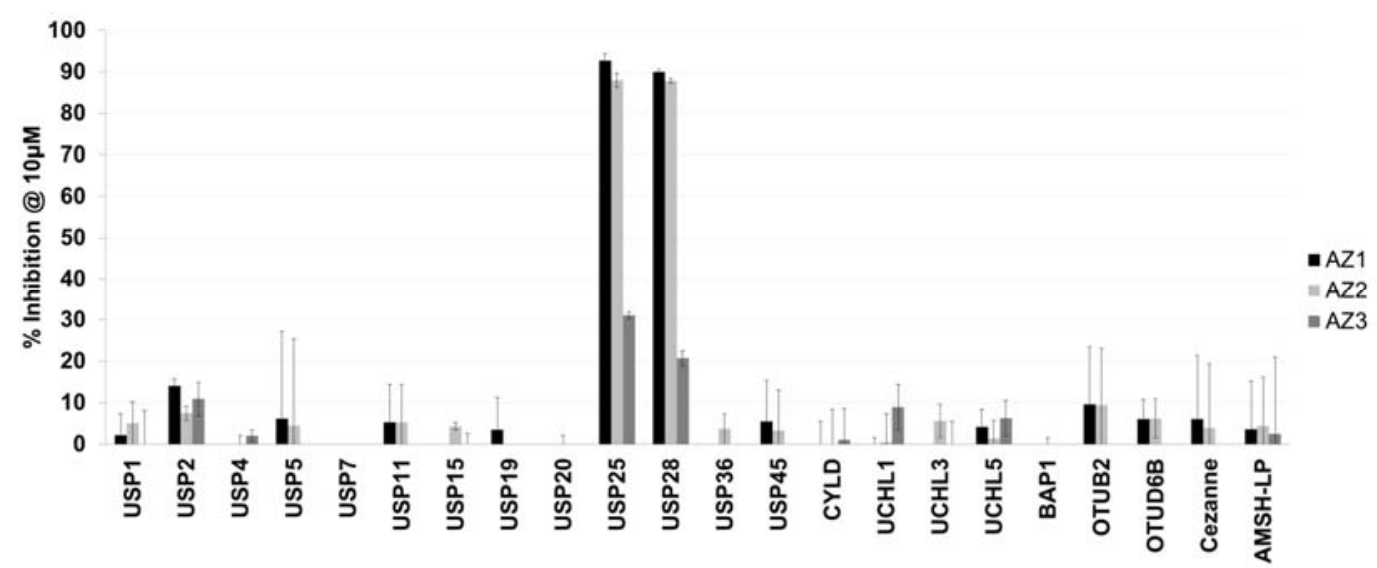

(a) Selectivity profiling of USP28 inhibitors across DUB family members.

Compound activity was analysed against a range of DUB family members, in the DUBProfiler panel (Ubiquigent) of purified enzyme assays using Ubiquitin-Rhodamine110 as substrate (28). Data is shown as a percentage of inhibition of the total enzyme activity for each enzyme in the panel, in the presence of $10 \mu \mathrm{M}$ test compound. Error bars represent the standard deviation of 3 replicates. 


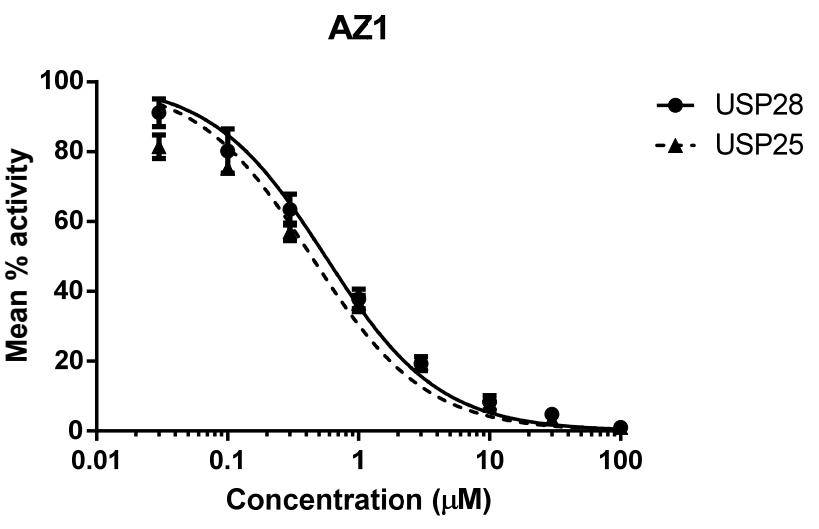

(b)

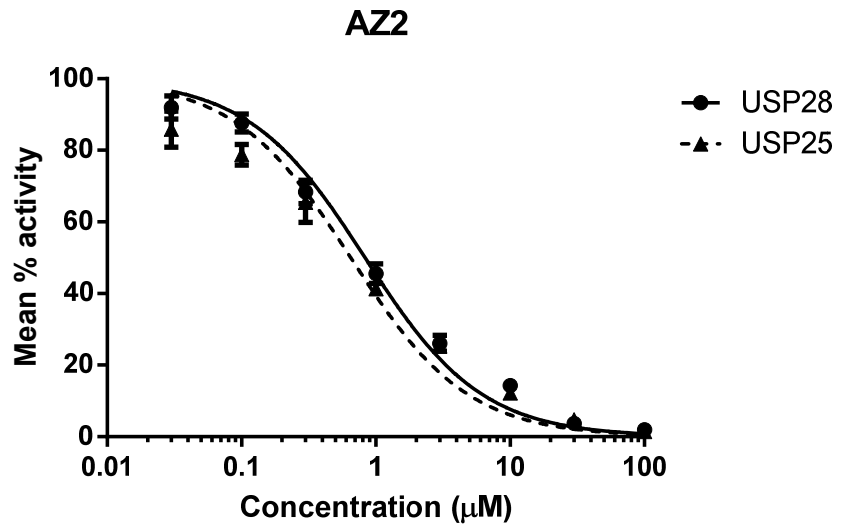

(c)

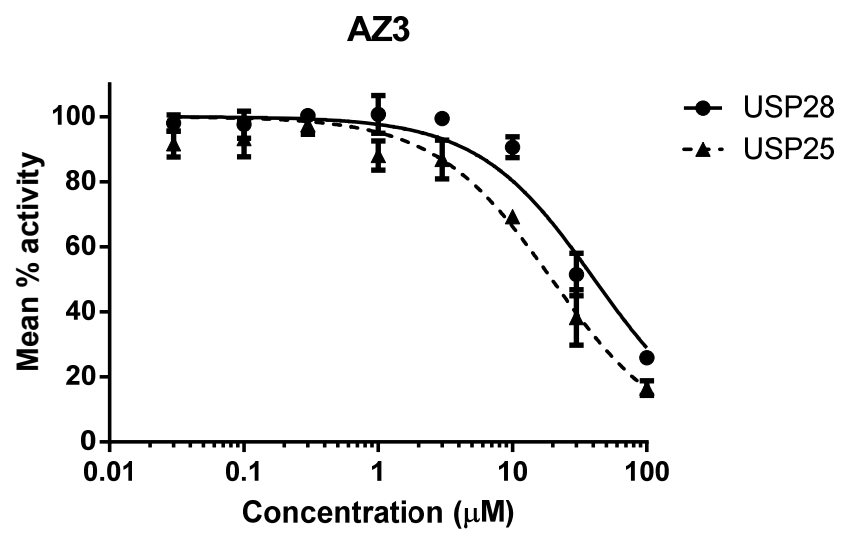

(d)

\begin{tabular}{|c|c|c|}
\hline & $\mathrm{USP}_{25} \mathrm{IC}_{50}(\mu \mathrm{M})$ & $\mathrm{USP}_{28} \mathrm{IC}_{50}(\mu \mathrm{M})$ \\
\hline $\mathrm{AZ1}$ & 0.7 & 0.6 \\
\hline AZ2 & 0.9 & 0.9 \\
\hline AZ3 & 26.4 & 52.5 \\
\hline
\end{tabular}

(e) 
Figure 2(b-e): Dose response profiling of inhibitors against USP25 \& USP28.

Compound activity was analysed against USP25 \& USP28, in the DUBProfiler (Ubiquigent) purified enzyme assays using UbiquitinRhodamine110 as substrate. Data is shown as a mean percentage activity at each concentration tested, thereby generating dose-response curves for (b) AZ1, (c) AZ2, and (d) AZ3. Error bars represent the standard deviation of 4 replicates. $\mathrm{IC}_{50}$ values calculated from the dose response curves are shown in the associated table (e). 
Figure 3: Cellular target engagement profiling of inhibitors

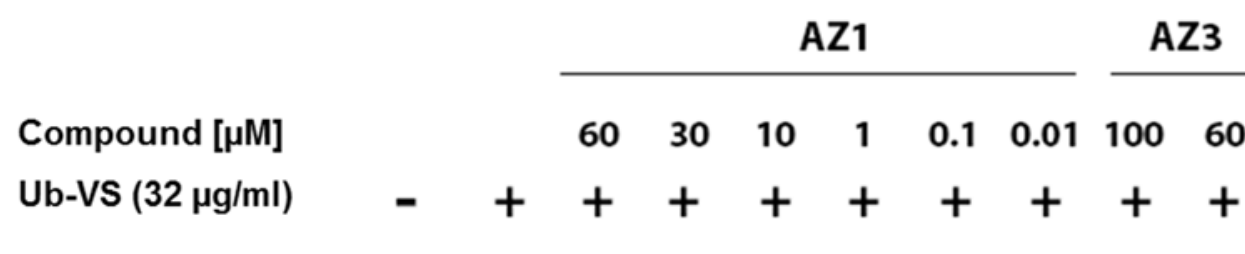

USP $28+\mathrm{Ub}$

USP28

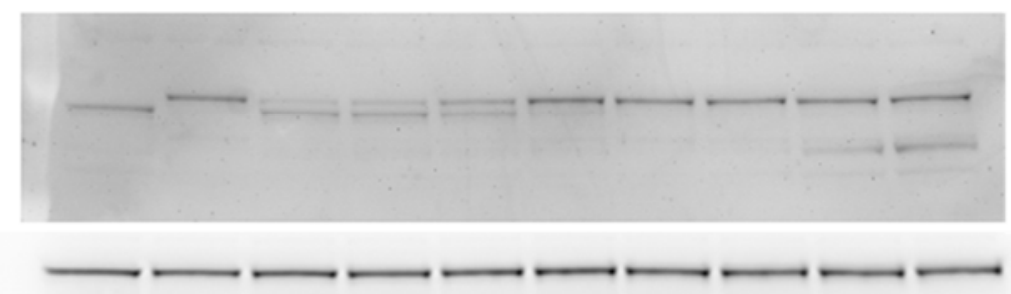

Vinculin

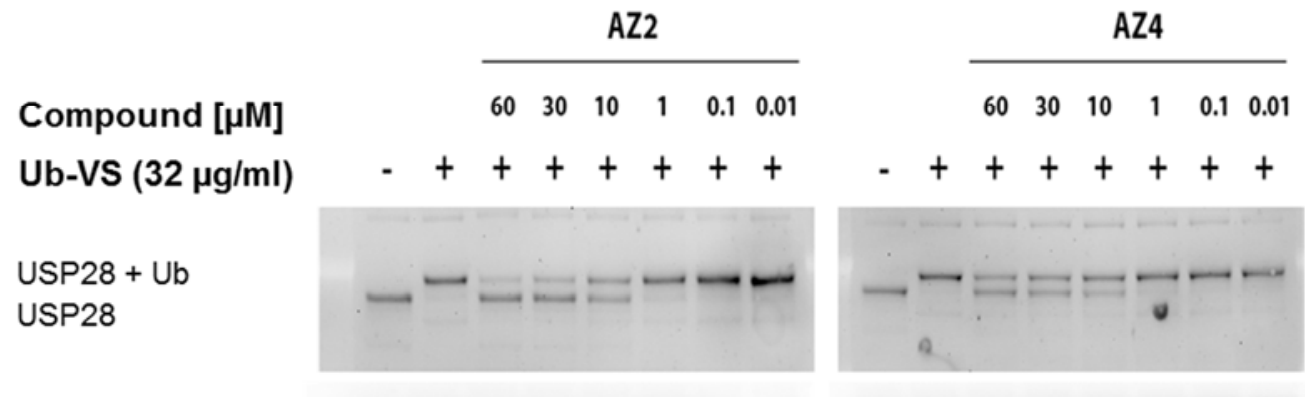

$---\omega-\omega$

Vinculin

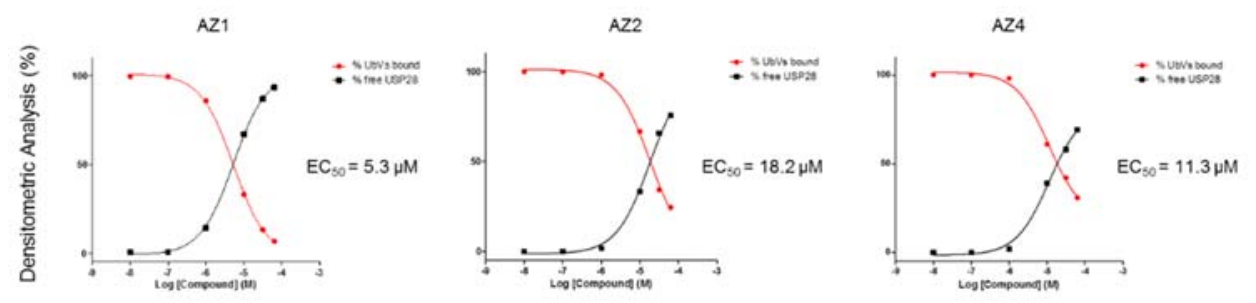

\begin{tabular}{|c|c|c|c|c|}
\hline Compound & AZ1 & AZ2 & AZ3 & AZ4 \\
\hline $\mathrm{EC}_{50}(\mu \mathrm{M})$ & $5.3+/-2.1$ & $18.2+/-5.2$ & $>100$ & $11.3+/-3.1$ \\
\hline
\end{tabular}

(a) Target engagement of USP28 in a cellular environment by USP28 inhibitors. HCT116 cells were treated with USP28 inhibitors at the indicated concentrations for $2 \mathrm{hrs}$. Cells were washed thrice, lysed and the Ub-VS probe added to the extract. Samples were analysed by immunoblotting probing for USP28. Upper band (USP28-Ub covalent adduct). Data presented as mean of 3 independent experiments. Quantitation by densitometry analysis was 
performed on both the upper (enzyme $+\mathrm{Ub}$ ) and lower bands (enzyme only). The data were fitted to a sigmoidal curve using GraphPad Prism (GraphPad Software, Inc, La Jolla, CA). 

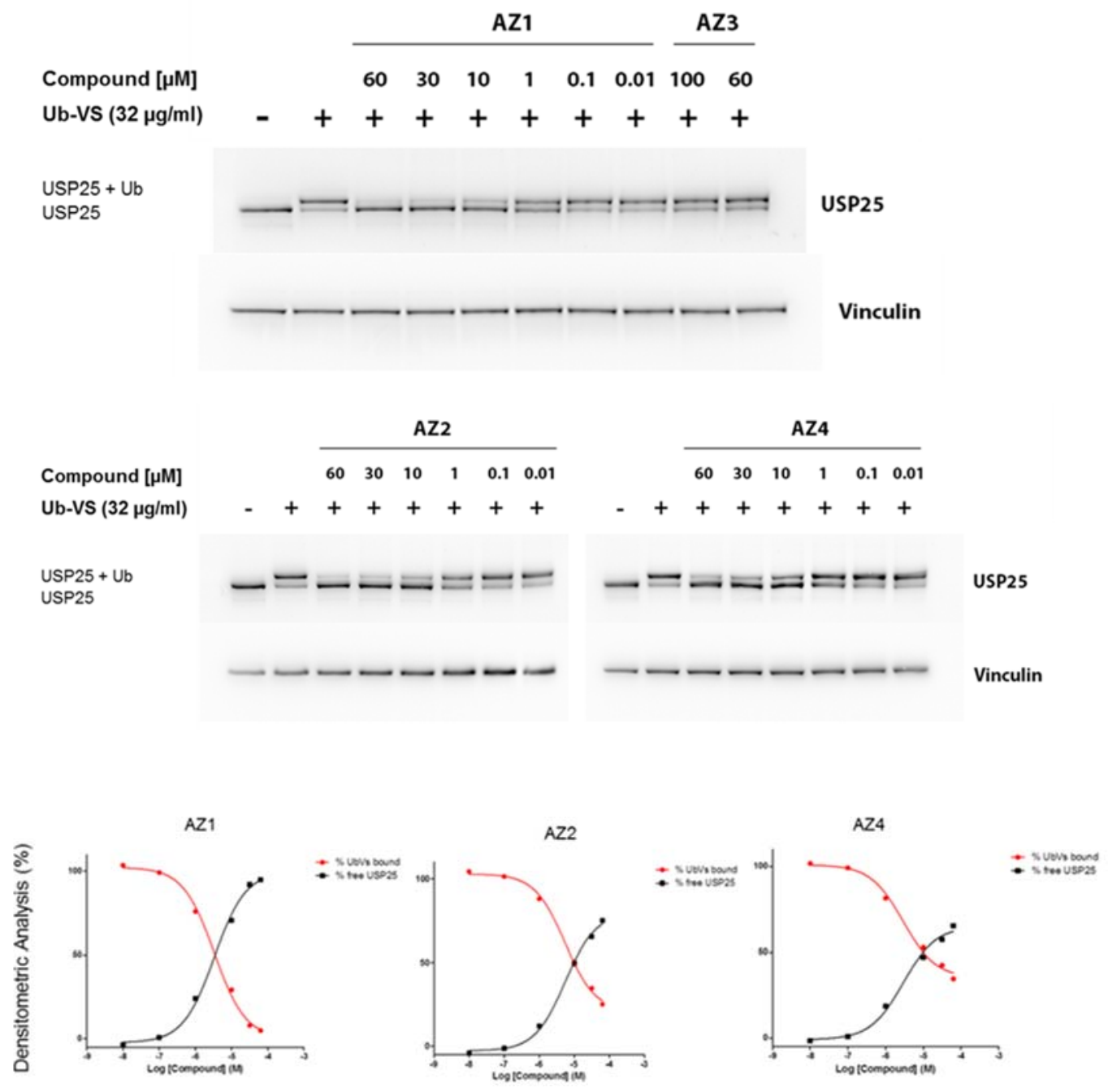

\begin{tabular}{|c|c|c|c|c|}
\hline Compound & AZ1 & AZ2 & AZ3 & AZ4 \\
\hline EC50 $(\mu \mathrm{M})$ & $3.3+/-1.2$ & $11.5+/-4.5$ & $>100$ & $19.6+/-3.2$ \\
\hline
\end{tabular}

\section{(b) USP28 inhibitors engage with USP25 in a cellular context}

HCT116 cells were treated with USP28 inhibitors at the indicated concentrations for $2 \mathrm{hrs}$. Cells were washed thrice, lysed and the Ub-VS probe added to the extract. Samples were analysed by immunoblotting probing for USP25. The higher bands show USP-Ub covalent adducts, demonstrating target engagement with USP25. Data presented as mean of 3 independent experiments. 


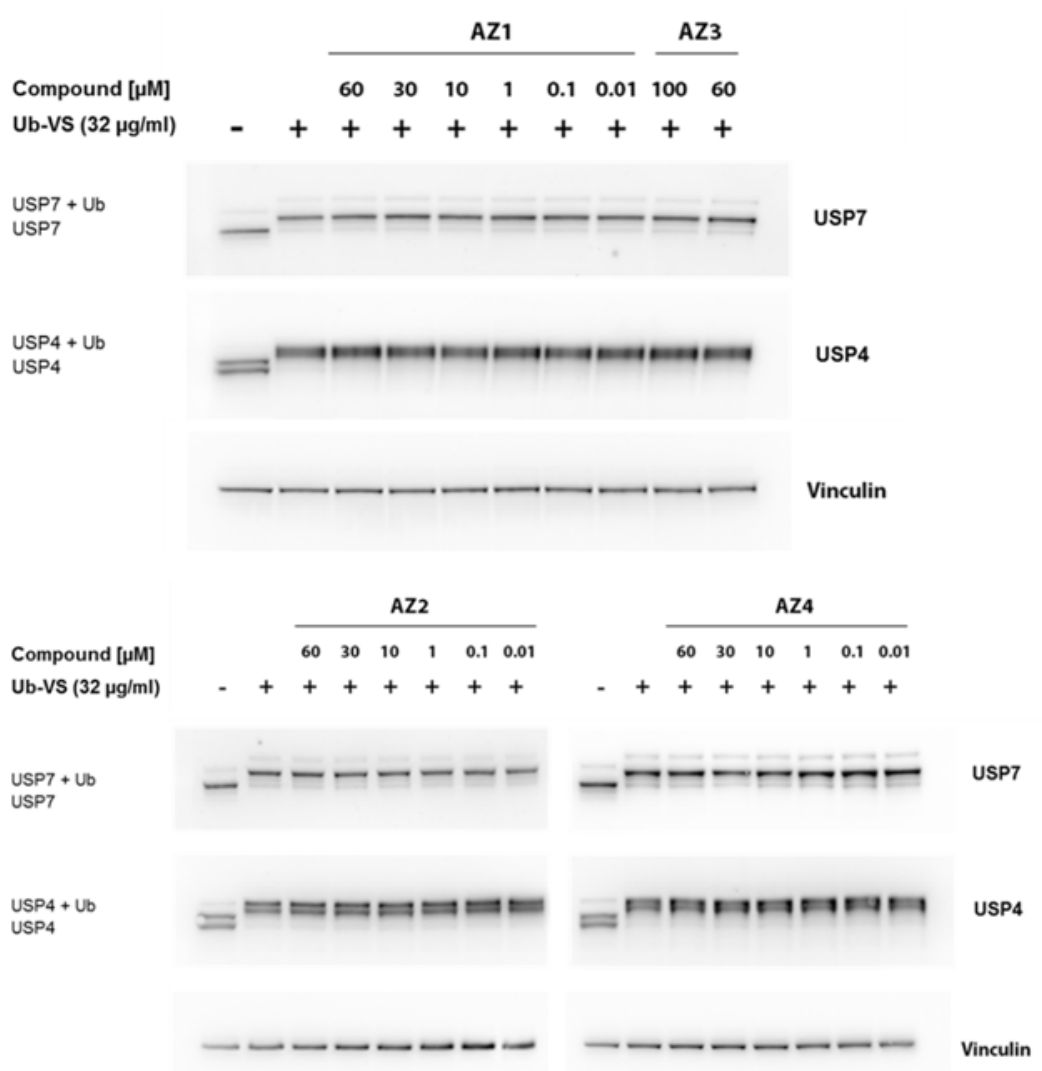

(c) USP28 inhibitors do not engage with USP7 or USP4 in a cellular context

HCT116 cells were treated with USP28 inhibitors at the indicated concentrations for $2 \mathrm{hrs}$. Cells were washed thrice, lysed and the Ub-VS probe added to the extract. Samples were analysed by immunoblotting probing for USP7 \& USP4. The higher bands show USP-Ub covalent adducts, with no demonstrable target engagement with either USP7 or USP4. Data presented as mean of 3 independent experiments. 
Figure 4: Phenotypic profiling of inhibitors

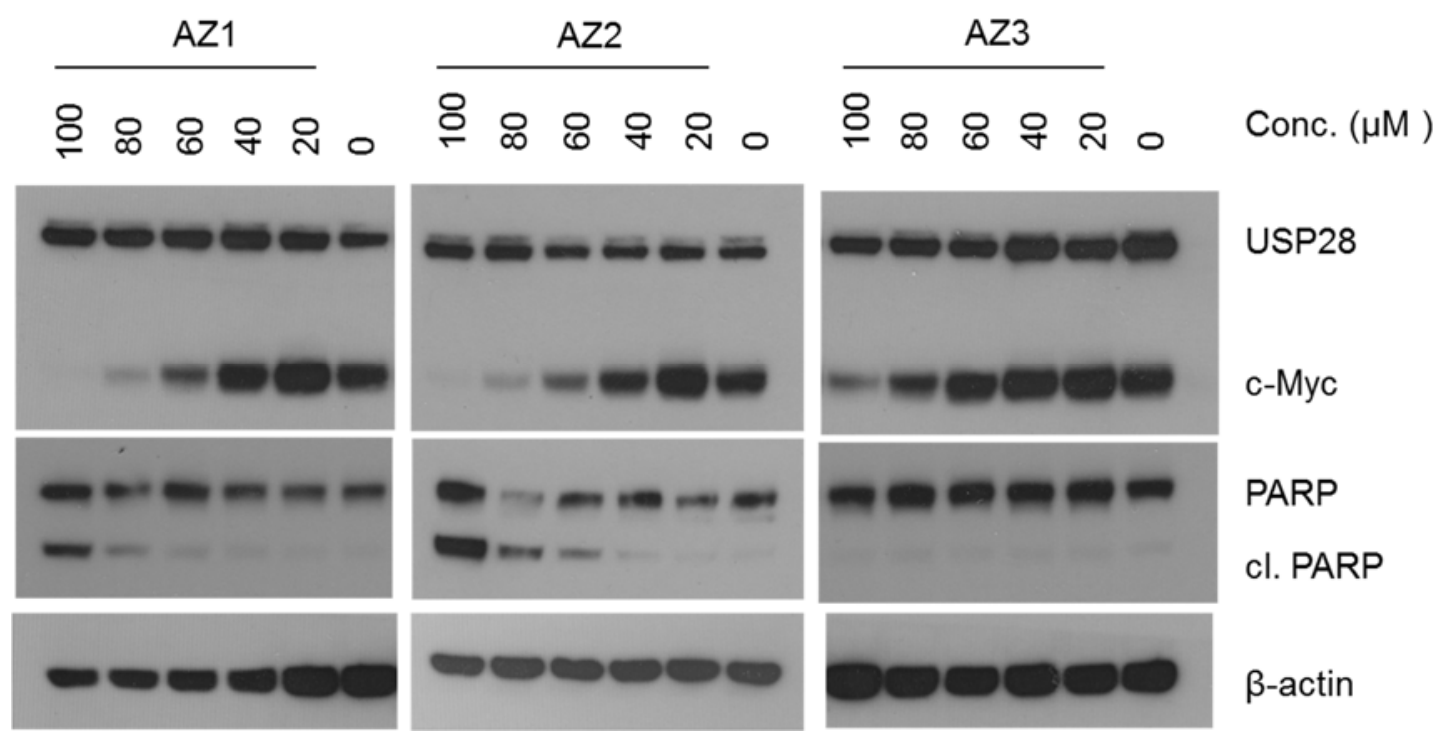

(a) Modulation of endogenous total c-Myc levels by USP28 inhibitors.

HCT116 cells were treated with compounds (as indicated) and samples collected after $3 \mathrm{hrs}$ for Western blot analysis probing for USP28, c-Myc and PARP. $\beta$ actin was included as loading control. Full-length PARP (116 kDa), cleaved PARP (cl. PARP, $85 \mathrm{kDa}$ ). These data are representative data from at least 3 independent experiments. Similar observations were also made in additional cell lines including SW480 and HT29 (see Fig. S3a-b) 


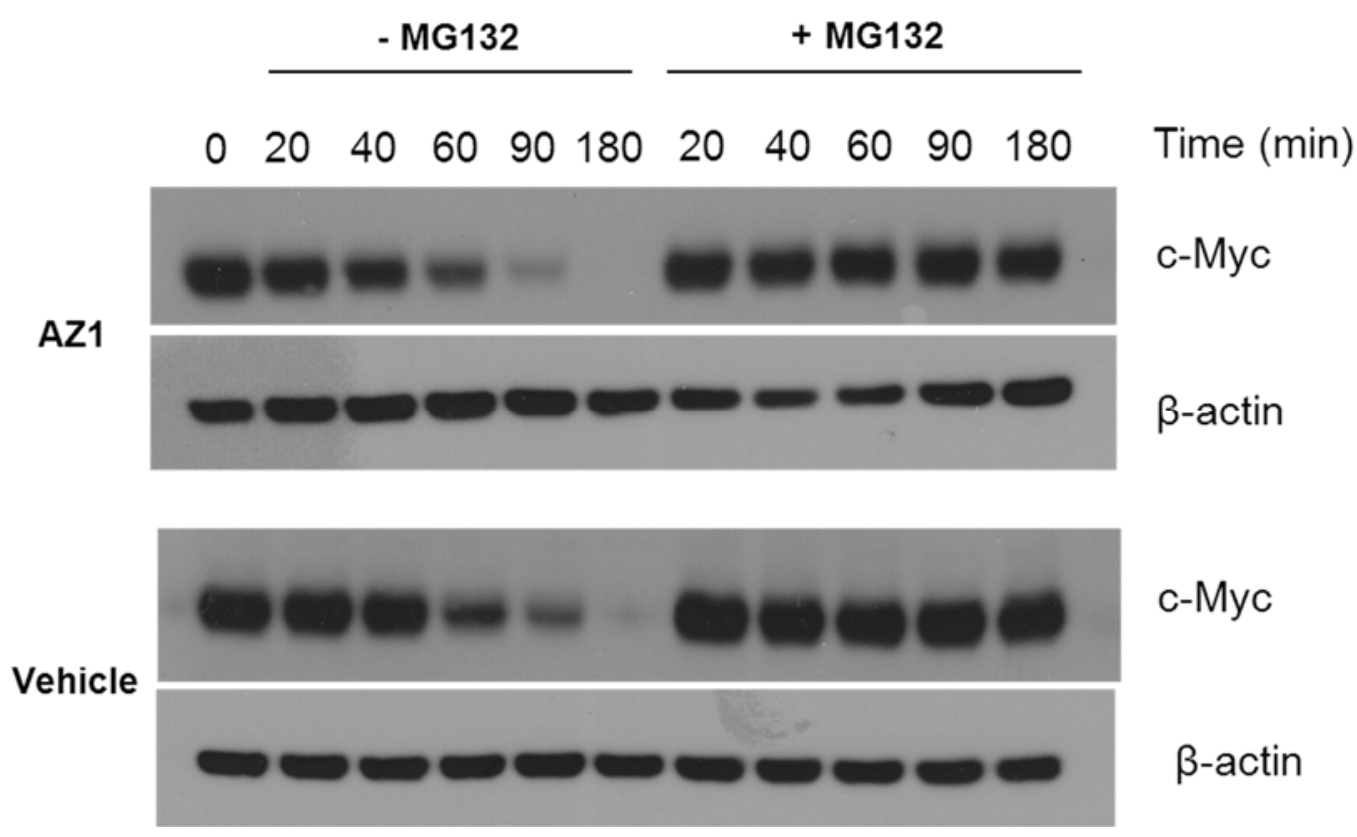

(b) USP28 inhibitor-induced c-Myc degradation is mediated by the proteasome. Representative data shown with AZ1. HCT116 cells were pretreated with cycloheximide $(100 \mu \mathrm{g} / \mathrm{mL})$ and the proteasome inhibitor MG132 $(20 \mu \mathrm{M})$ and subsequently exposed to AZ1 $(60 \mu \mathrm{M})$ or vehicle control (DMSO). Cells were lysed at the indicated timepoints (from 0 to $180 \mathrm{~min}$ ) and samples analysed by Western blotting probing for c-Myc. The half-life values of c-Myc were determined by densitometry analysis based on these blots. $\beta$-actin was included as loading control. These data are representative data from at least 3 independent experiments. 
Figure 5: Representative cell cycle and viability assays in HCT116 and viability data across a panel of cell lines including normals.
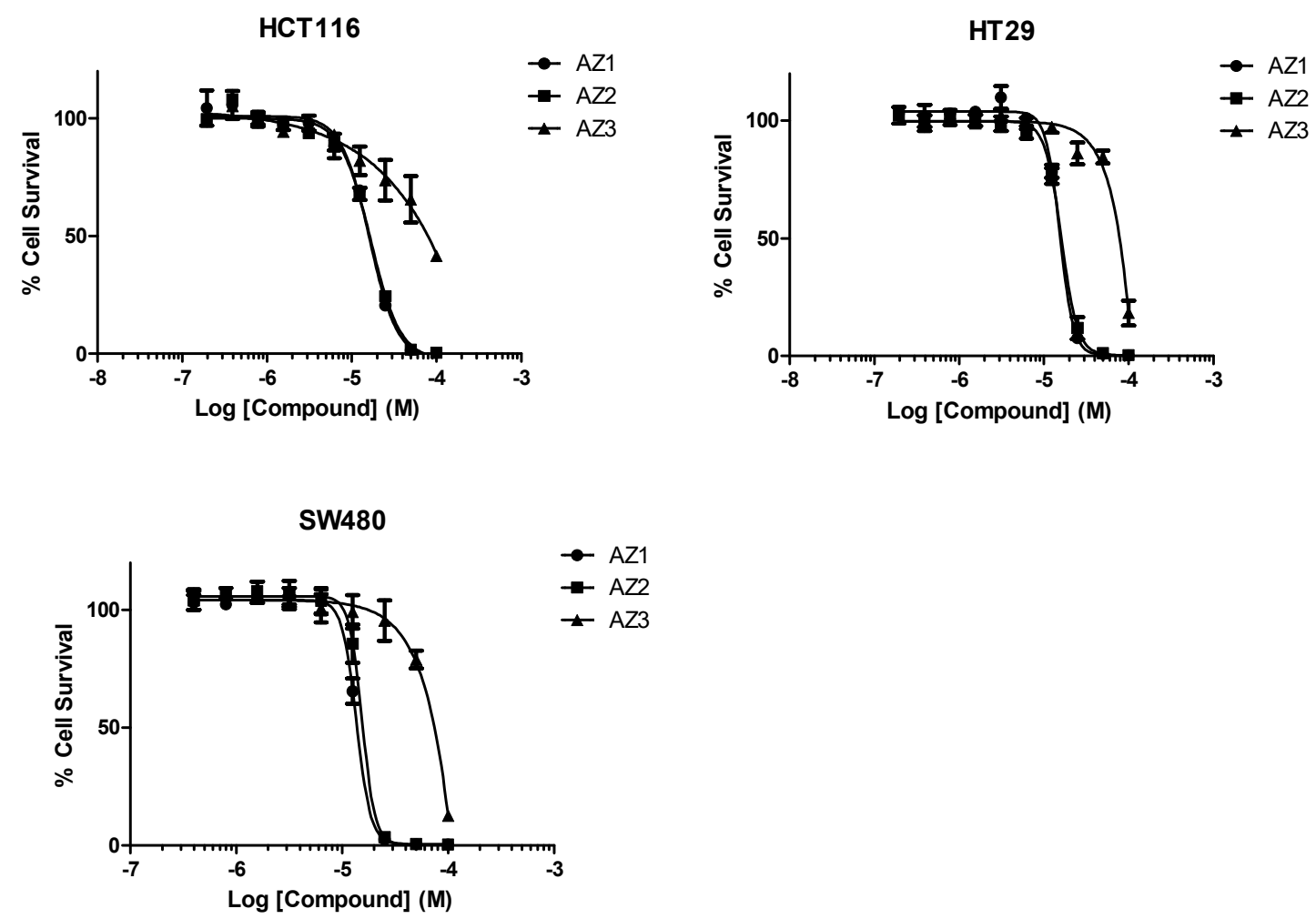

(a) Cell viability assays - Cells were typically seeded in 96 well plate format (typically 4000-6000 cells/well) and treated after $24 \mathrm{hrs}$ with increasing concentration of compound from 0 to $100 \mu \mathrm{M}$ in $1 / 2$ $\log$ unit increments. Cell viability was assessed after $72 \mathrm{hrs}$ by CellTiter-Glo ${ }^{\circledR}$ as recommended by the manufacturer's instructions (Promega). Analysis and $\mathrm{EC}_{50}$ values were derived using GraphPadPrism (GraphPad Software, Inc, La Jolla, CA; fourparameter logistic function). Data presented as mean of at least three independent experiments. $\mathrm{EC}_{50}$ values compiled in Supplementary Table 1. 


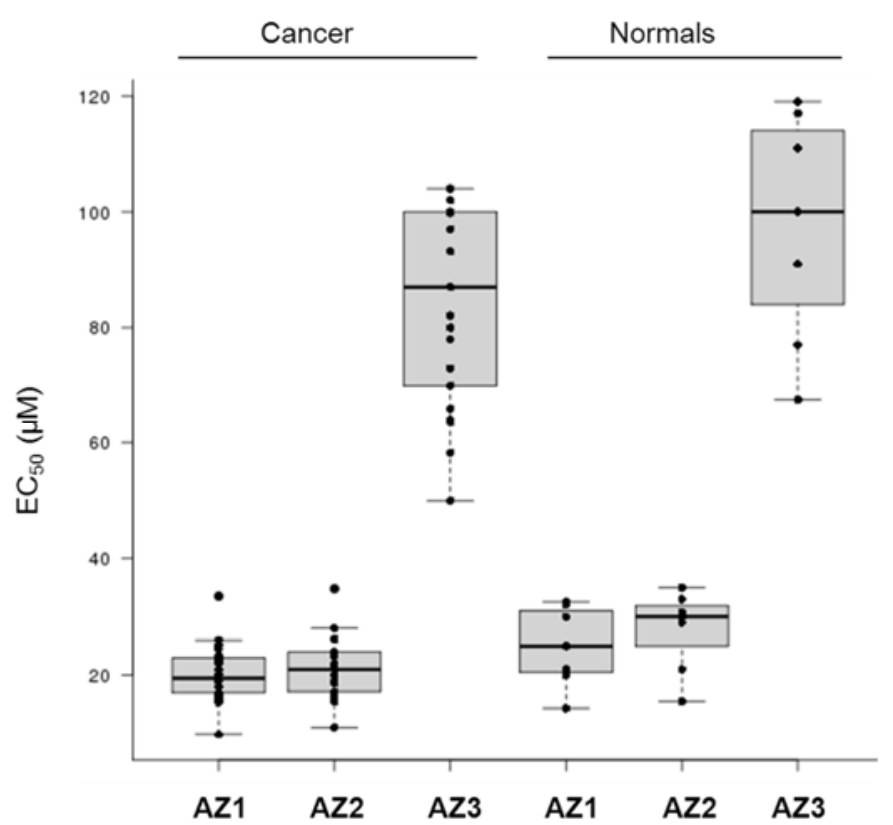

(b) Representative viability assays in a panel of cancer and tissuematched normal cell lines.

Compiled EC50 values in normal and cancer cell lines. Proliferation assays were run as described previously using a panel of cancer $(n=21)$ and normal cell lines $(n=7)$ from different tissues of origin. EC 50 values were derived using GraphPad Prism (GraphPad Software, Inc, La Jolla, CA) from at least two independent experiments. Cell line panel composition and $\mathrm{EC}_{50}$ values are available in Supporting information. The box plot representation was performed using $\mathrm{R}+\mathrm{GG}$ plot2 package. The tick band indicates the median, the box indicates the upper and lower quantiles, the vertical line indicates the variability and the individual dots represent the various cell lines. Details on the panel composition and $\mathrm{EC}_{50}$ values are shown in Supplementary Table 1. 
Title:

Identification and characterisation of dual inhibitors of the USP25/28 Deubiquitinating enzyme subfamily.

\section{Authors:}

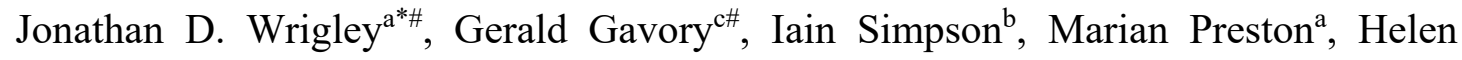
Plant $^{\mathrm{a}}$, Jenna Bradley ${ }^{\mathrm{a}}$, Anne U. Goeppert ${ }^{\mathrm{a}}$, Ewelina Rozycka ${ }^{\mathrm{c}}$, Gareth Davies ${ }^{\mathrm{a}}$, Jarrod Walsh $^{\mathrm{a}}$, Andrea Valentine ${ }^{\mathrm{c}}$, Keeva McClelland ${ }^{\mathrm{c}}$, Krzysztofa Ewa Odrzywol ${ }^{\mathrm{c}}$, Jonathan Renshaw $^{\mathrm{a}}$, Joanna Boros ${ }^{\mathrm{a}}$, Jonathan Tart ${ }^{\mathrm{a}}$, Lindsey Leach ${ }^{\mathrm{a}}$, Thorsten Nowak ${ }^{\mathrm{b}}$, Richard A. Ward ${ }^{\mathrm{b}}$, Timothy Harrison ${ }^{\mathrm{c}} \&$ David M Andrews ${ }^{\mathrm{b}}$ \#Joint Co-authors

\section{Supplementary Information}




\section{Supplementary Methods:}

\section{Expression and purification of USP28}

The extended catalytic domain of the USP28 (E147-L652) LE-6his was expressed in the BL21*(DE3) E.coli transformed with pET29b vector grown in Terrific broth. 21 hours post induction the grow was harvested by centrifugation. The cell pellets were resuspended $1 \mathrm{~g}$ per $10 \mathrm{ml}$ in lysis buffer of $20 \mathrm{mM}$ Hepes pH8.0, $0.15 \mathrm{M} \mathrm{NaCl}, 5 \mathrm{mM}$ 2-mercaptoethanol, $10 \mathrm{mM}$ Imidazole containing Complete-EDTA free protease inhibitors (Roche) and $50 \mu \mathrm{g} / \mathrm{ml}$ lysozyme. Lysis was performed by sonication on ice and clarified by centrifugation. The supernatant was applied to a Nickel-NTA superflow (Qiagen) column equilibrated into $20 \mathrm{mM}$ Hepes (pH8.0), 0.15 M NaCl, 5 $\mathrm{mM}$ 2-mercaptoethanol, $10 \mathrm{mM}$ Imidazole. After loading the column was washed to remove unbound with the same running buffer. The tagged protein was eluted using this buffer containing $250 \mathrm{mM}$ imidazole. The elution fractions were pooled and concentrated using a cleaned Amicon Ultra-15 centrifugal filter with a 10,000 MWCO membrane (Millipore). The pool was loaded onto a Hiload Superdex 200 16/60 prep grade (GE Healthcare) equilibrated into $25 \mathrm{mM}$ Bis-Tris (pH7.0), $0.1 \mathrm{M} \mathrm{NaCl}, 4 \mathrm{mM}$ TCEP storage buffer. The pure USP28 pool was concentrated further, aliquoted and snap frozen for storage.

\section{In vitro deubiquitination assays using Ubiquitin-Rhodamine 110}

\section{Assay Reagents}

Ubiquitin-Rhodamine 110 was from Boston Biochem. All other chemicals were supplied from Sigma-Aldrich.

\section{Assay buffer}

All reactions were performed at room temperature in freshly prepared assay buffer containing $50 \mathrm{mM}$ Hepes (pH 7.4), $0.5 \mathrm{mM}$ EDTA, $1 \mathrm{mM}$ tris-(2-Carboxyethyl) phosphine (TCEP) and $1 \mathrm{mg} / \mathrm{ml}$ bovine serum albumin.

\section{Compound Preparation}


Compounds were acoustically dispensed into black 1536-well non-binding microplates (Greiner Bio-One, UK) using an Echo 555 (Labcyte Inc., Sunnyvale, CA). For primary screening, $10 \mathrm{~nL}$ of $10 \mathrm{mM}$ compounds solubilized in DMSO were dispensed acoustically into the wells. This gave a final concentration of $0.3 \%(\mathrm{v} / \mathrm{v})$ DMSO and a final in-well compound concentration of $33.3 \mu \mathrm{M}$ after addition of all reagents. For concentration-response screening, varying amounts of compound were dispensed acoustically to give a doubling dilution range. Wells were backfilled with the required volume of DMSO to ensure a final concentration of $1 \%(\mathrm{v} / \mathrm{v})$ after addition of all reagents.

\section{Assay Optimization}

Cleavage of the rhodamine Ubiquitin-Rhodamine 110 was confirmed by incubating $80 \mathrm{nM}$ Ubiquitin-Rhodamine 110 in assay buffer with $0.25 \mathrm{nM}$ USP28 in a final volume of $6 \mu \mathrm{L}$. The fluorescence signal was read every 5 minutes for $35 \mathrm{~min}$. The effect of different reductants on enzyme activity was determined by incubating $80 \mathrm{nM}$ Ubiquitin-Rhodamine 110 with $0.25 \mathrm{nM}$ USP28 in assay buffer containing either 1 $\mathrm{mM}$ dithiothreitol (DTT), glutathione or TCEP. Kinetic parameters for the USP28catalyzed cleavage of $\mathrm{nM}$ Ubiquitin-Rhodamine 110 were determined by incubating varying concentrations of Ubiquitin-Rhodamine 110 with $0.25 \mathrm{nM}$ USP28. The fluorescence signal was read on a Pherastar microplate reader (BMG Labtech, Ortenberg, Germany) using excitation $485 \mathrm{~nm}$, emission $520 \mathrm{~nm}$, every minute for 30 min. Initial rate data were fitted to the Michaelis-Menten equation using GraphPad Prism V.5 (GraphPad Software Inc.).

\section{Inhibition of USP28 by Ubiquitin aldehyde}

$0.25 \mathrm{nM}$ USP28 in assay buffer was incubated with varying concentrations of Ubiquitin aldehyde. These were incubated at room temperature for 20 minutes, prior to the addition of $80 \mathrm{nM}$ Ubiquitin-Rhodamine 110. The plates were covered and left to incubate for a further $30 \mathrm{mins}$ at room temperature. $100 \mathrm{mM}$ citric acid was added before measuring fluorescence as before. The $\mathrm{IC}_{50}$ data were fitted using GraphPad Prism (GraphPad Software, La Jolla, CA). 


\section{High throughput screen for USP28 inhibitors}

Test compounds from the AstraZeneca compound collection were dissolved in DMSO to form stock solutions (10 mM). A final concentration of $0.3 \% \mathrm{v} / \mathrm{v}$ of DMSO and 10 $\mu \mathrm{M}$ test compound was achieved after reagent additions. An Innovadyne Nanodrop (PAA, Colorado) was used to dispense $1.5 \mu \mathrm{L}$ of $0.5 \mathrm{nM}$ USP28 in assay buffer (50 mM Hepes (pH 7.5), $0.5 \mathrm{mM}$ EDTA, $0.1 \mathrm{mg} / \mathrm{ml}$ BSA, $1 \mathrm{mM}$ TCEP) to assay plates containing compound, before briefly centrifuging the plates at $150 \mathrm{~g}$ for 10 seconds in a Vspin (Agilent, Santa Clara, CA). After 20 minutes incubation at room temperature, $1.5 \mu \mathrm{L}$ of $160 \mathrm{nM}$ Ubiquitin-Rhodamine 110 in assay buffer was added using a Nanodrop and the plates centrifuged as before. The reaction was incubated at room temperature for 30 minutes, before the addition of $1.5 \mu \mathrm{l}$ of $100 \mathrm{mM}$ citric acid using a Latitude (Deerac Fluidics, Sunnyvale, CA) to stop the reaction. Fluorescence signal was measured as before.

\section{Concentration Response Follow-up Screening}

8-point, doubling dilution concentration-response curves, with a top concentration of $100 \mu \mathrm{M}$ were constructed. The assay was performed using the process described for the high-throughput compound library screening. Assay using the tetra-ubiquitin Rh110 substrate (tetra-Ub Rh110 K63-linked; \# UC355; Boston Biochem) was performed as described above for the Ub-Rh110 substrate using commercially available USP28 (Boston biochem, \# E-570). The fluorescence polarisation (FP) assay was performed as described above using instead the isopeptide ubiquitin-Lystetramethylrhodamine substrate (Ub-TMR; U-558, Boston Biochem). FP was measured every $15 \mathrm{~min}$ over a period of $90 \mathrm{~min}$ (within the linear range of the assay) using a Synergy 4 plate reader (BioTek) exciting at $530 \mathrm{~nm}$ and measuring the amount of parallel and perpendicular light at $575 \mathrm{~nm}$. The FP signal was subsequently normalised to the no compound control (i.e. DMSO). Analysis and IC50 values were derived using GraphPadPrism (GraphPad Software, Inc, La Jolla, CA; four-parameter logistic function). All data presented as mean \pm s.d. $(n>=3)$.

\section{Mode of inhibition study}

AZ1 at final assay concentrations ranging from $200 \mathrm{nM}$ to $5 \mu \mathrm{M}$ was pre-incubated for $30 \mathrm{~min}$ with $1.5 \mathrm{nM}$ of full-length USP28 ( $0.5 \mathrm{nM}$ final assay concentration). Five 
microliters of tetra-ubiquitin substrate (Tetra-Ub K63-linked; $100 \mathrm{nM}$ to $40 \mu \mathrm{M}$ to a final assay volume of $15 \mu \mathrm{l}$ in low volume black 384-well plates (Greiner \# 784076). Fluorescence intensity $(\mathrm{ex}=487-14 \mathrm{~nm}$, em $=535-30 \mathrm{~nm})$ was measured over $90 \mathrm{~min}$ using a CLARIOstar plate reader (BMG LABTECH) and initial linear rates were calculated. Global fit analysis for competitive models were performed using GraFit (Leatherbarrow, R.J. (2001) GraFit Version 5, Erithacus Software Ltd., Horley, U.K.; Global fit Michaelis-Menten enzyme inhibition).

\section{Data analysis}

HTS data were analyzed using proprietary AstraZeneca software.

\section{Reversibility studies}

For the high-dilution assay, USP28 was pre-incubated for 30 min with 10x the inhibitor $\mathrm{IC}_{50}$ value followed by 100x dilution. USP28 activity was assessed $15 \mathrm{~min}$ post-dilution as described above. Iodoacetamide (Sigma-Aldrich; \#A3221) was used as a positive control for this experiment at a final pre-dilution concentration of 1.0 $\mathrm{mM}$. Data analysis was performed as described previously.

\section{"Ratio test" assay}

8-point, doubling dilution concentration-response curves, with a top concentration of $100 \mu \mathrm{M}$ were constructed. The assay was performed using the process described for the high-throughput compound library screening. A further assay was performed on the same set of compounds using a concentration of $5 \mathrm{nM}$ USP2 8 and an incubation time of 3 minutes.

\section{Binding Assays - Nanotemper}

$20 \mu \mathrm{M}$ USP28 was labeled with a red fluorescent dye (NT-647) using Monolith NT TM Protein Labelling Kit RED (NanoTemper Technologies GmbH, Munich, Germany). Phosphate buffered saline (PBS) containing $0.4 \mathrm{mM}$ TCEP and $0.3 \%$ $(\mathrm{v} / \mathrm{v})$ Tween-20 was used as the assay buffer for compound and protein dilutions. Compounds were serially diluted in doubling dilutions to generate 16-point concentration ranges with final assay concentrations between $100 \mu \mathrm{M}$ and $0.003 \mu \mathrm{M}$. Labelled USP28 was diluted to a final assay concentration of $50 \mathrm{nM} .20 \mu$ of diluted compound was mixed with $20 \mu \mathrm{l}$ of diluted fluorescently labelled protein and 
incubated under ambient conditions for 30 minutes. Each compound / protein mixture was spun for 5 minutes at $13,000 \mathrm{rpm}$ prior to aspiration into a glass capillary to minimise uptake of aggregated particulate. 16 samples could be analysed within one MST experiment. The utilisation of hydrophilic glass capillaries was necessary due the propensity of USP28 to bind to untreated glass surfaces. Analysis was performed on a Monolith NT using the following settings: Infra-red laser power at $25 \%$, laser on time (heating) $=30$ seconds, laser off time (cooling) $=5$ seconds. The data were normalised against the baseline obtained in the absence of any inhibitor, and the maximal response obtained at the highest concentration of inhibitor. The (dissociation constant) ( $\left.\mathrm{K}_{\mathrm{d}}\right)$ was calculated by plotting delta Fnorm (shift in normalised fluorescence) against the logarithm of the compound dilution series concentrations. The resulting sigmoidal binding curve could be directly fitted with a non-linear solution of the law of mass action. All experiments were performed with a minimum of 3 replicates and the delta Fnorm curves analysed using Origin software (OriginLab Corporation, Northampton, MA, USA).

\section{Flow cytometry}

Cells were plated in $6 \mathrm{~cm}$ dish $\left(2.5 \times 10^{5}\right.$ cells/well $)$ and treated with compounds as indicated. Cells (including floating cells) were collected after 24 or $48 \mathrm{hrs}$, rinsed with PBS/FCS (1\%, v/v) and fixed with $70 \% \mathrm{EtOH}$ and kept at $4{ }^{\circ} \mathrm{C}$ until needed. Cells were subsequently stained with Propidium Iodide solution $(100 \mu \mathrm{g} / \mathrm{mL}$ PI in 1x PBS) and incubated at RT for $30 \mathrm{~min}$. Cell cycle analysis was performed using flow cytometry (FACScalibur) and the CellQuest Software.

\section{Chemistry:}

Compounds AZ1-4 were prepared as described below.

$\underline{\text { 2-(5-Bromo-2-(4-fluoro-3-(trifluoromethyl)benzyloxy)benzylamino)ethanol, AZ1 }}$<smiles>OCCNCc1cc(Br)ccc1OCc1ccc(F)c(C(F)(F)F)c1</smiles> 
Potassium carbonate (2.75 g, $19.90 \mathrm{mmol}$ ) was added to 4-(bromomethyl)-1-fluoro-2(trifluoromethyl)benzene $(2.81 \mathrm{~g}, 10.94 \mathrm{mmol})$ and 5-bromo-2-hydroxybenzaldehyde ( $2 \mathrm{~g}, 9.95 \mathrm{mmol})$ in DMF $(50 \mathrm{~mL})$ at $20^{\circ} \mathrm{C}$ under nitrogen. The resulting yellow suspension was stirred at $20{ }^{\circ} \mathrm{C}$ for $16 \mathrm{hrs}$. The reaction mixture was then poured into ice water, the resulting white precipitate filtered, washed with copious water and dried under vacuum to give 5-bromo-2-(4-fluoro-3(trifluoromethyl)benzyloxy)benzaldehyde (3.61 g, 96 \%) as a white solid. 2aminoethanol $(0.922 \mathrm{~mL}, 15.27 \mathrm{mmol})$ was added to 5-bromo-2-(4-fluoro-3(trifluoromethyl)benzyloxy)benzaldehyde (1.44 g, $3.82 \mathrm{mmol})$ in THF (35 mL) with acetic acid ( 2 drops) added under nitrogen. The solution was then stirred for 10 mins. Sodium triacetoxyhydroborate $(2.428 \mathrm{~g}, 11.45 \mathrm{mmol})$ was then added portionwise over 30 minutes and the resulting suspension was stirred at $20^{\circ} \mathrm{C}$ for $16 \mathrm{hrs}$. The reaction mixture was then poured onto $10 \% \mathrm{NaHCO}_{3}$ solution $(200 \mathrm{~mL})$ and the aqueous phase was extracted with ethyl acetate $(2 \times 200 \mathrm{~mL})$. The combined organic phases were dried over $\mathrm{Na}_{2} \mathrm{SO}_{4}$, filtered and evaporated to give a yellow gum. The crude product was purified by flash silica chromatography, elution gradient 0 to $10 \%$ $\mathrm{MeOH}$ in DCM. Pure fractions were combined and evaporated to dryness to afford 2(5-bromo-2-(4-fluoro-3-(trifluoromethyl)benzyloxy)benzylamino)ethanol (1.23 g, $76 \%$ ) as a white solid. ${ }^{1} \mathrm{H}$ NMR (400 MHz, D6-DMSO, $\left.22^{\circ} \mathrm{C}\right) 2.17(1 \mathrm{H}, \mathrm{s}), 2.55(2 \mathrm{H}$, t), $3.44(2 \mathrm{H}, \mathrm{dt}), 3.70(2 \mathrm{H}, \mathrm{s}), 4.48(1 \mathrm{H}, \mathrm{t}), 5.20(2 \mathrm{H}, \mathrm{s}), 7.01(1 \mathrm{H}, \mathrm{d}), 7.38(1 \mathrm{H}, \mathrm{dd})$, 7.46 - 7.65 (2H, m), 7.75 - 8 (2H, m) ppm; 13C-NMR (176 MHz, D6-DMSO, $22{ }^{\circ} \mathrm{C}$ ) 46.90, 51.11, 60.36, 67.98, 112.39, 114.14, 116.47 (dq, J=32.17, 12.91), 117.31 (d, $\mathrm{J}=20.38), 122.51$ (q, J=271.87), 125.97 - 126.11 (m), 129.94, 131.18, 132.02, 134.08, 134.13, 154.86, $158.31(\mathrm{~d}, \mathrm{~J}=254.92)$; HRMS + ESI $m / z$ calc. for $[\mathrm{M}+\mathrm{H}]^{+}$ $\mathrm{C}_{17} \mathrm{H}_{17} \mathrm{O}_{2} \mathrm{NBrF}_{4} 422.03733$, found 422.03738 .

\section{2-(5-bromo-2-(3-(trifluoromethoxy)benzyloxy)benzylamino)ethanol, AZ2}<smiles>OCCNCc1cc(Br)ccc1OCc1cccc(OC(F)(F)F)c1</smiles> 
Potassium carbonate (2.75 g, $19.90 \mathrm{mmol})$ was added to 1-(bromomethyl)-3(trifluoromethoxy)benzene $(2.79 \mathrm{~g}, \quad 10.94 \mathrm{mmol})$ and 5-bromo-2hydroxybenzaldehyde $(2.000 \mathrm{~g}, 9.95 \mathrm{mmol})$ in DMF $(50 \mathrm{~mL})$ at $20^{\circ} \mathrm{C}$ under nitrogen. The resulting yellow suspension was stirred at $20^{\circ} \mathrm{C}$ for $16 \mathrm{hrs}$. The reaction mixture was poured into ice water, the resulting white precipitate filtered off, washed with water and dried under vacuum at $50^{\circ} \mathrm{C}$. At this temperature, the product melted. The liquid was then dissolved in DCM, passed through phase separating cartridge and filtrate concentrated under reduced pressure to give 5-bromo-2-(3(trifluoromethoxy)benzyloxy)benzaldehyde (1.682 g, $45.1 \%$ ) as a pale yellow liquid that crystalised on standing to an off-white solid. 2-Aminoethanol $(1.081 \mathrm{~mL}, 17.91$ mmol) was added to 5-bromo-2-(3-(trifluoromethoxy)benzyloxy)benzaldehyde (1.680 $\mathrm{g}, 4.48 \mathrm{mmol})$ in THF (50 mL) with acetic acid (few drops) added under nitrogen. The solution was stirred for 10 mins. sodium triacetoxyhydroborate $(2.85 \mathrm{~g}, 13.44 \mathrm{mmol})$ was then added portionwise over 30 minutes and the resulting suspension was stirred at $20^{\circ} \mathrm{C}$ for $2 \mathrm{hrs}$. Reaction did not look to be progressing by TLC so heated to $50^{\circ} \mathrm{C}$ for $16 \mathrm{hrs}$. The reaction mixture was poured onto $10 \% \mathrm{NaHCO}_{3}$ solution $(200 \mathrm{~mL})$ and extracted with ethyl acetate $(2 \times 200 \mathrm{~mL})$. The organics were dried over $\mathrm{Na}_{2} \mathrm{SO}_{4}$, filtered and evaporated to give a yellow gum. The crude product was purified by flash silica chromatography, elution gradient 0 to $10 \% \mathrm{MeOH}$ in DCM. Pure fractions were evaporated to dryness to afford 2-(5-bromo-2-(3(trifluoromethoxy)benzyloxy)benzylamino)ethanol (1.521 g, $81 \%)$ as a white solid. ${ }^{1} \mathrm{H}$ NMR (400 MHz, DMSO, 22 $\left.{ }^{\circ} \mathrm{C}\right) 2.57(2 \mathrm{H}, \mathrm{t}), 3.43(2 \mathrm{H}, \mathrm{d}), 3.72(2 \mathrm{H}, \mathrm{s}), 4.50(1 \mathrm{H}$, s), $5.19(2 \mathrm{H}, \mathrm{s}), 7.00(1 \mathrm{H}, \mathrm{d}), 7.26-7.41(2 \mathrm{H}, \mathrm{m}), 7.51(4 \mathrm{H}, \mathrm{m}) \mathrm{ppm} ;{ }^{13} \mathrm{C}-\mathrm{NMR}(176$ MHz, D6-DMSO, $\left.22{ }^{\circ} \mathrm{C}\right)$ 46.89, 51.14, 60.40, 68.45, 112.31, 114.09, 119.42, 120.0 (q, J=256.36) 120.11, 126.10, 129.86, 130.42, 131.08, 132.08, 139.77, 148.41, 154.89; HRMS +ESI $\mathrm{m} / \mathrm{z}$ calc. for $[\mathrm{M}+\mathrm{H}]^{+} \mathrm{C}_{17} \mathrm{H}_{18} \mathrm{O}_{3} \mathrm{NBrF}_{3}$ 420.04167, found 420.04221 .

AZ3 and AZ4 were made in analogous manner to the preparations of AZ1 and AZ2 above. AZ3 and AZ4 exhibited the following analytical data:

\section{$\underline{\text { 2-\{[2-(benzyloxy)-5-bromobenzyl }] \text { amino }\} \text { ethanol, AZ3 }}$}


<smiles>OCCNCc1cc(Br)ccc1OCc1ccccc1</smiles>

${ }^{1} \mathrm{H}$ NMR (400 MHz, DMSO, 22 $\left.{ }^{\circ} \mathrm{C}\right) 2.14(1 \mathrm{H}, \mathrm{s}), 2.55$ (2H, dd), 3.46 (2H, q), 3.71 $(2 \mathrm{H}, \mathrm{s}), 4.49(1 \mathrm{H}, \mathrm{t}), 5.13(2 \mathrm{H}, \mathrm{s}), 7.01(1 \mathrm{H}, \mathrm{d}), 7.29$ - $7.48(6 \mathrm{H}, \mathrm{m}), 7.50(1 \mathrm{H}, \mathrm{d})$; ${ }^{13} \mathrm{C}-\mathrm{NMR}$ (176 MHz, DMSO) 44.03, 48.84, 56.23, 69.88, 111.78, 114.70, 122.65, $127.52,127.89,128.40,132.86,133.73,136.37,155.81$; HRMS ESI+ $m / z$ calc. for $\mathrm{C}_{16} \mathrm{H}_{18} \mathrm{BrNO}_{2}, 336.05937$, found 336.05978.

\section{$\underline{\text { 2-(\{5-Bromo-2-[(2,4,5-trifluorobenzyl)oxy]benzyl }\} \text { amino }) \text { ethanol, AZ4 }}$}<smiles>OCCNCc1cc(Br)ccc1OCc1cc(F)c(F)cc1F</smiles>

${ }^{1} \mathrm{H}$ NMR (400 MHz, DMSO, $\left.21^{\circ} \mathrm{C}\right) 2.02(1 \mathrm{H}, \mathrm{s}), 2.53(2 \mathrm{H}, \mathrm{t}), 3.44(2 \mathrm{H}, \mathrm{q}), 3.67(2 \mathrm{H}$, s), $4.47(1 \mathrm{H}, \mathrm{t}), 5.13(2 \mathrm{H}, \mathrm{s}), 7.07(1 \mathrm{H}, \mathrm{d}), 7.39(1 \mathrm{H}, \mathrm{dd}), 7.51(1 \mathrm{H}, \mathrm{d}), 7.597 .76(2 \mathrm{H}$, $\mathrm{m})$

${ }^{13} \mathrm{C}-\mathrm{NMR}\left(176 \mathrm{MHz}, \mathrm{D} 6-\mathrm{DMSO}, 22{ }^{\circ} \mathrm{C}\right)$ 46.79, 51.06, 60.39, 63.11, 106.14 (dd, J = 21.4, 28.2), 112.62, 114.24, 118.08 (dd, J = 5.3, 19.9), 120.89 (dt, J = 16.4), 129.93, 131.15, 132.21, 145.98 (ddd, $\mathrm{J}=242.71,12.72$, 3.09), 149.05 (dt, $\mathrm{J}=250.02$, 13.66), 154.77, $155.50(\mathrm{dd}, \mathrm{J}=245.17,9.48)$; HRS $+\mathrm{ESI} \mathrm{m} / \mathrm{z}$ calc. for $\mathrm{C}_{16} \mathrm{H}_{15} \mathrm{BrF}_{3} \mathrm{NO}_{2}$ $[\mathrm{M}+\mathrm{H}]^{+}$390.03110, found 390.03311 . 


\section{Supplementary Results/Discussion:}

\section{USP28 screening and hit identification.}

The Ub-Rh110 assay was chosen based on its superior optical properties to alternatives such as Ubiquitin-AMC, whose emission/excitation wavelengths $(\sim 360 / \sim 460 \mathrm{~nm})$ correspond to a spectrum range over which small molecule compounds typically absorb or emit, potentially resulting in assay artefacts. This strategy was also favoured based on the feasibility and simplicity of such an approach, compared to the complexities of utilising a cell-based assay for analysis of c-Myc levels, which would require significant deconvolution of hits, due to the range of additional factors that could impact on cellular c-Myc levels.

As part of our assay set-up and validation activities, initial studies were performed to determine the optimal enzyme and substrate concentrations and a suitable time course for the reaction (data not shown). The selected conditions of $80 \mathrm{nM} \mathrm{Ub-Rho110} \mathrm{and}$ $0.25 \mathrm{nM}$ USP28 yielded linear time-dependant cleavage, and an approximately 3 -fold signal : noise window at the chosen 30 minutes assay timepoint (Fig.S1a). The Michaelis-Menten parameters were determined by monitoring the rate of reaction at several different concentrations of substrate. A $\mathrm{K}_{\mathrm{m}}$ value of $1918 \pm 100 \mathrm{nM}$ for UbRh110 versus USP28 was determined (Fig. S1b). For comparison, this value is similar to the $\mathrm{K}_{\mathrm{m}}$ value of $1137 \pm 93 \mathrm{nM}$ derived in a previous screen for USP2a. A substrate concentration of $80 \mathrm{nM}$ was chosen for screening ( 25 -fold below the $K_{m}$ value) in order to identify competitive inhibitors.

Based on previous observations with an in vitro Ub-AMC assay for USP7, the choice of reducing agent included in the assay may have a significant impact on both assay performance and the nature of the hits identified (12). For this reason, we performed studies to analyse the effect of several reducing agents on the assay window (Fig.S1c). This demonstrated that although a signal was obtained under all conditions, the assay window was the highest using $1 \mathrm{mM}$ TCEP, which was therefore chosen for subsequent use. Another crucial step in assay validation was to demonstrate that a known inhibitor showed activity in this assay format. To this aim, Ubiquitin aldehyde (Ub-Al) was tested at a range of concentrations to generate a dose response curve, which yielded an $\mathrm{IC}_{50}$ value of $6.4 \mathrm{nM}$ (Fig. 1Sd). Assay robustness and 
reproducibility were also determined and monitored by multiple testing using Ub-Al as positive control. Assay statistical analyses demonstrated good reproducibility both within and between assays and also yielded $Z^{\prime}$ values of around 0.8 , demonstrating in turn good assay robustness (data not shown).

Assay performance was monitored throughout the campaign by means of controls for the maximum signal and $50 \%$ and $100 \%$ inhibition, to ensure reproducibility of the assay signal and inhibition. Whilst DMSO was used as a control for the maximal signal, a previously reported inhibitor of USP7 was also utilised for the inhibitory controls (Compound 1j/B, Patent: WO 2007/066200 A2). Z' values were monitored throughout testing and values $>0.7$ were consistently generated throughout primary and follow-up screening (data not shown).

A primary hit rate of approximately $5.3 \%$ was obtained and the compound inhibition data yielded the expected bell-shaped distribution around a median of approximately $0 \%$ inhibition (Fig. S1e).

Based on this assay, a validation rate of $36 \%$ was obtained leading to an overall hit rate of $0.3 \%(15 / 40000)$ for the entire screen. Our subsequent characterisation, commencing with $\mathrm{IC}_{50}$ determination, focused exclusively on these likely-specific inhibitors.

\section{Biophysical Techniques:}

NanoTemper Microscale Thermophoresis (MST) was employed to confirm compound binding and this technique involved labelling of the USP28 target protein with a red fluorescent dye (NT-647) or utilised its intrinsic fluorescence. The target was then treated with a serial dilution of unlabelled compounds in a glass capillary. An infrared laser was used to generate precise microscopic temperature gradients in the capillary and the motion of fluorescently labelled molecules along these gradients is measured. Ligand binding to a target protein alters the enveloping hydration shell causing unbound and ligand-bound protein to respond differently to the thermophoretic force allowing determination of binding affinities. 


\section{Effects on Cell Cycle:}

To investigate the effect of the compounds over a longer period of time, flow cytometry analysis was performed. HCT116 cells were treated with various concentrations of the compounds (typically 10, 20 and $40 \mu \mathrm{M}$ ), fixed and stained with Propidium Iodide (PI) after 24 and $48 \mathrm{hrs}$ of treatment. Under the conditions of these experiments, this analysis revealed that AZ1 and AZ2 induced cell death in a dosedependent manner as evidenced by the accumulation of a sub-G1 population. Whilst the effect was clearly noticeable at $24 \mathrm{hrs,} \mathrm{apoptosis} \mathrm{induction} \mathrm{was} \mathrm{particularly} \mathrm{strong}$ following $40 \mu \mathrm{M}$ compound treatment after $48 \mathrm{~h}(25 \% v s>60 \%$; Fig. S4). At lower concentrations $(<20 \mu \mathrm{M})$, the cell cycle profiles were directly comparable to the control. No significant effects were observed on the cell cycle profiles following treatment of cells with the less active analogue AZ3 at $48 \mathrm{hrs}$ (up to $40 \mu \mathrm{M}$ ). 


\section{Supplementary Figures:}

Figure S1: Characterisation of USP28 in vitro enzyme activity, assay development and screening.

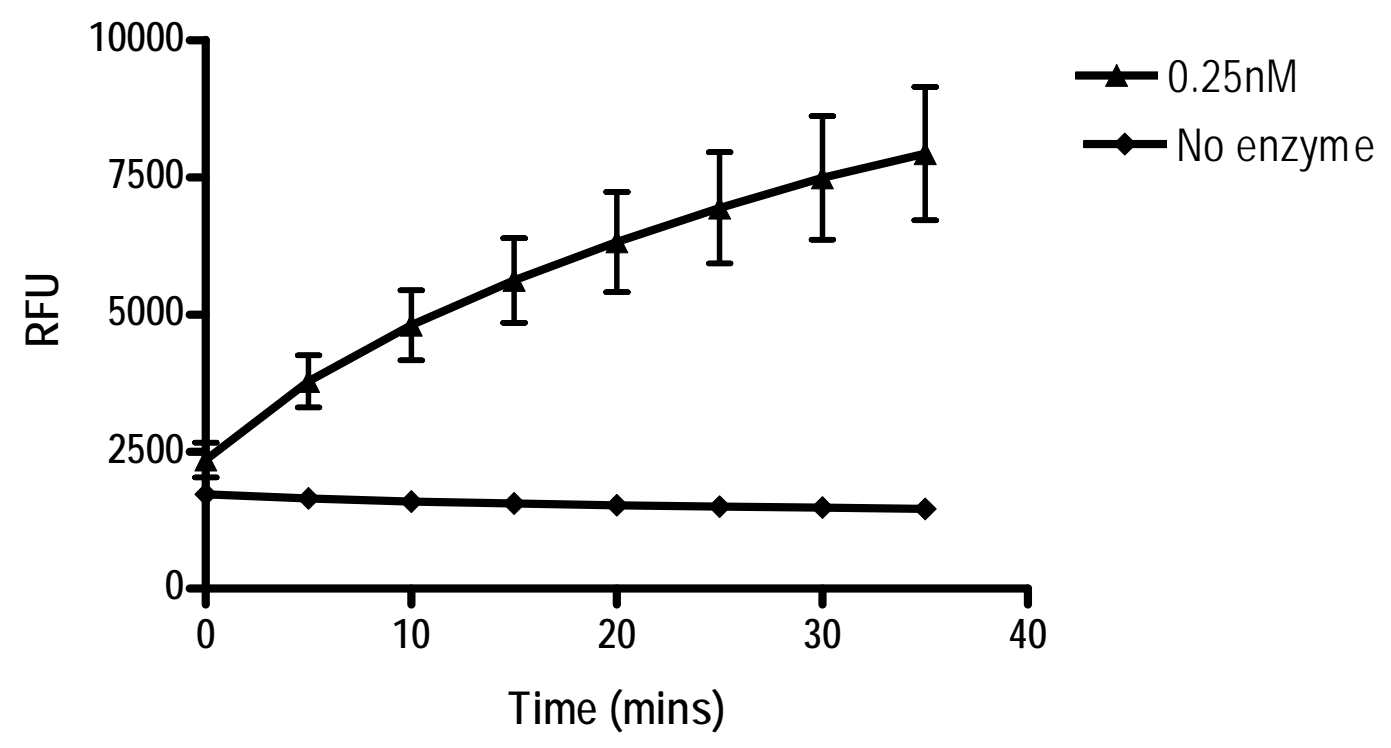

(a) Representative reaction progress and assay signal following the cleavage of Ubiquitin-Rhodamine 110 by USP28. Reaction time course of $80 \mathrm{nM}$ Ubiquitin-Rhodamine 110 and $0.25 \mathrm{nM}$ USP28. The graph shows representative data from one of three independent experiments. The data are the mean of the three replicates from that experiment and the error bars are the standard deviation of the replicates within the experiment. 


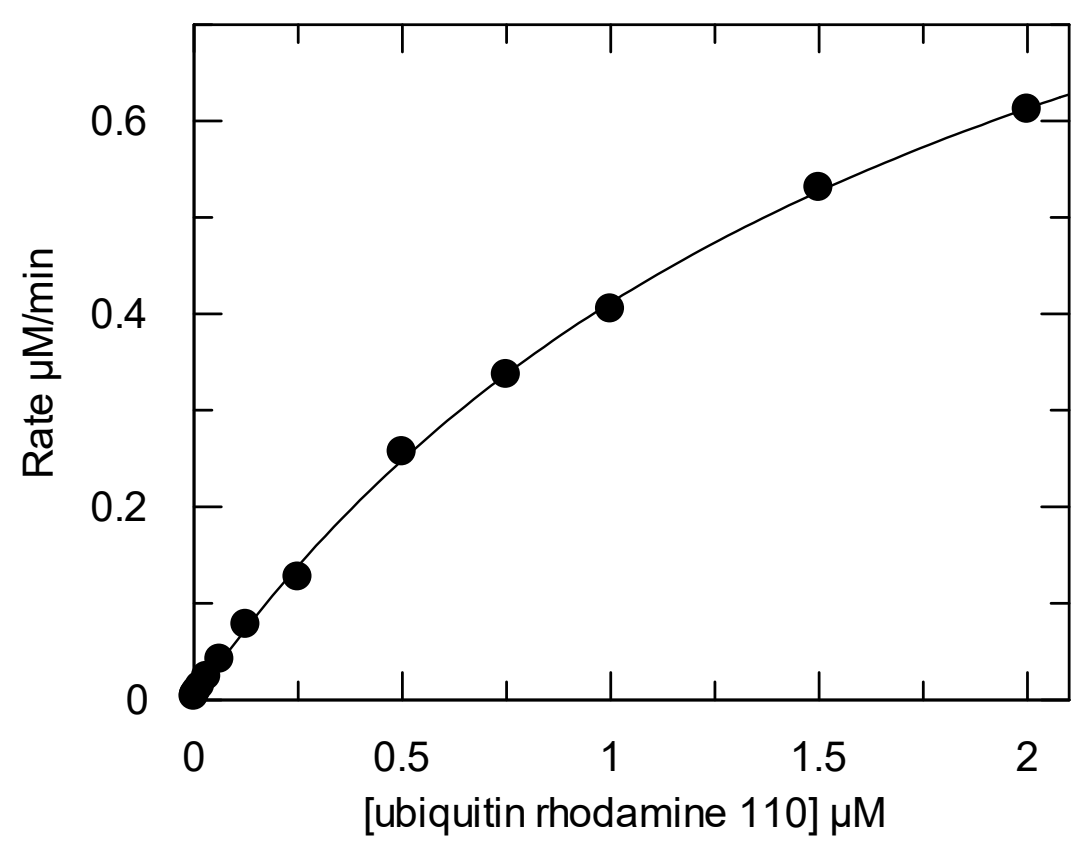

(b) Determination of the $K_{m}$ of USP28 for Ubiquitin-Rhodamine 110. Varying concentrations of Ubiquitin-Rhodamine 110 were incubated in the presence of $0.25 \mathrm{nM}$ USP28. The diagram shows the mean of $\mathrm{n}=4$ data from one of two independent experiments. The initial rate data were fitted to the MichaelisMenten equation using GraFit V.7 (Erithacus Software, Surrey, UK), giving a $\mathrm{K}_{\mathrm{m}}$ value of $1918 \pm 100 \mathrm{nM}$. 


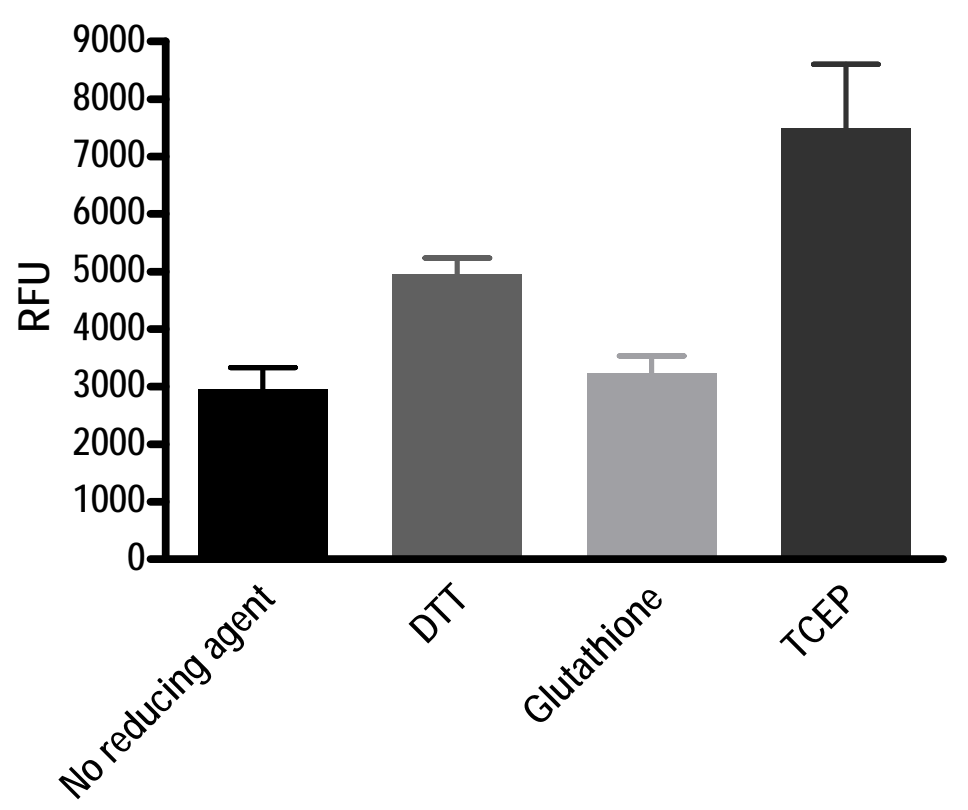

(c) Measuring the effect of different reducing agents on USP28 activity. 80 $\mathrm{nM}$ Ubiquitin-Rhodamine 110 was incubated with $0.25 \mathrm{nM}$ USP28 in the presence of different reducing agents tested at $1 \mathrm{mM}$. The data shown are representative data from a single experiment. The data are the mean of four replicates from that experiment and the error bars are the standard deviation of the replicates within the experiment. 


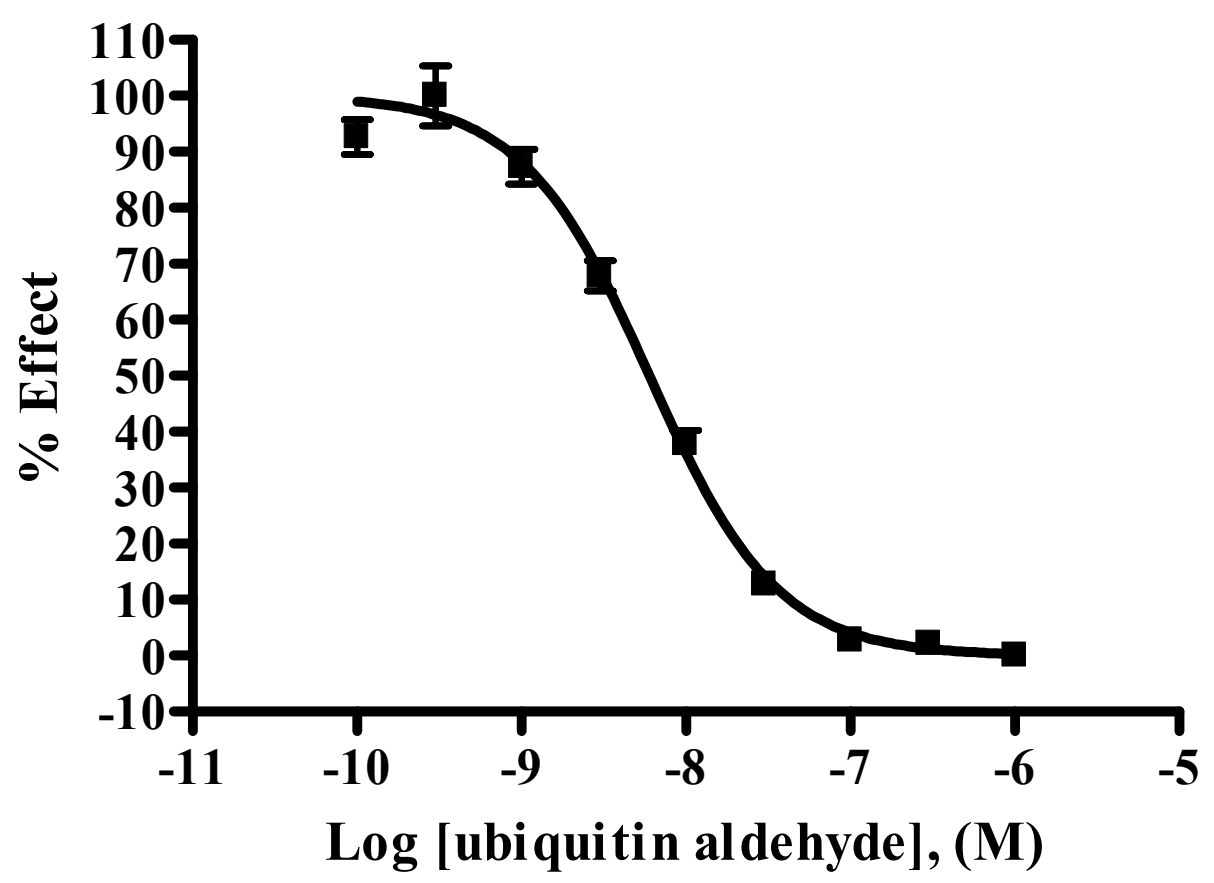

(d) Validation of the USP28 enzyme assay with Ubiquitin aldehyde. $80 \mathrm{nM}$ Ubiquitin-Rhodamine 110 was incubated with $0.25 \mathrm{nM}$ USP28 in the presence of different concentrations of Ubiquitin aldehyde (as indicated). The data shown are representative data from a single experiment. The data were fitted to a sigmoidal curve using GraphPad Prism (GraphPad Software, Inc, La Jolla, $\mathrm{CA})$, giving an $\mathrm{IC}_{50}$ value of $6.4 \mathrm{nM}(95 \%$ CIR 1.22). Error bars represent the standard deviation of 3 replicates. 


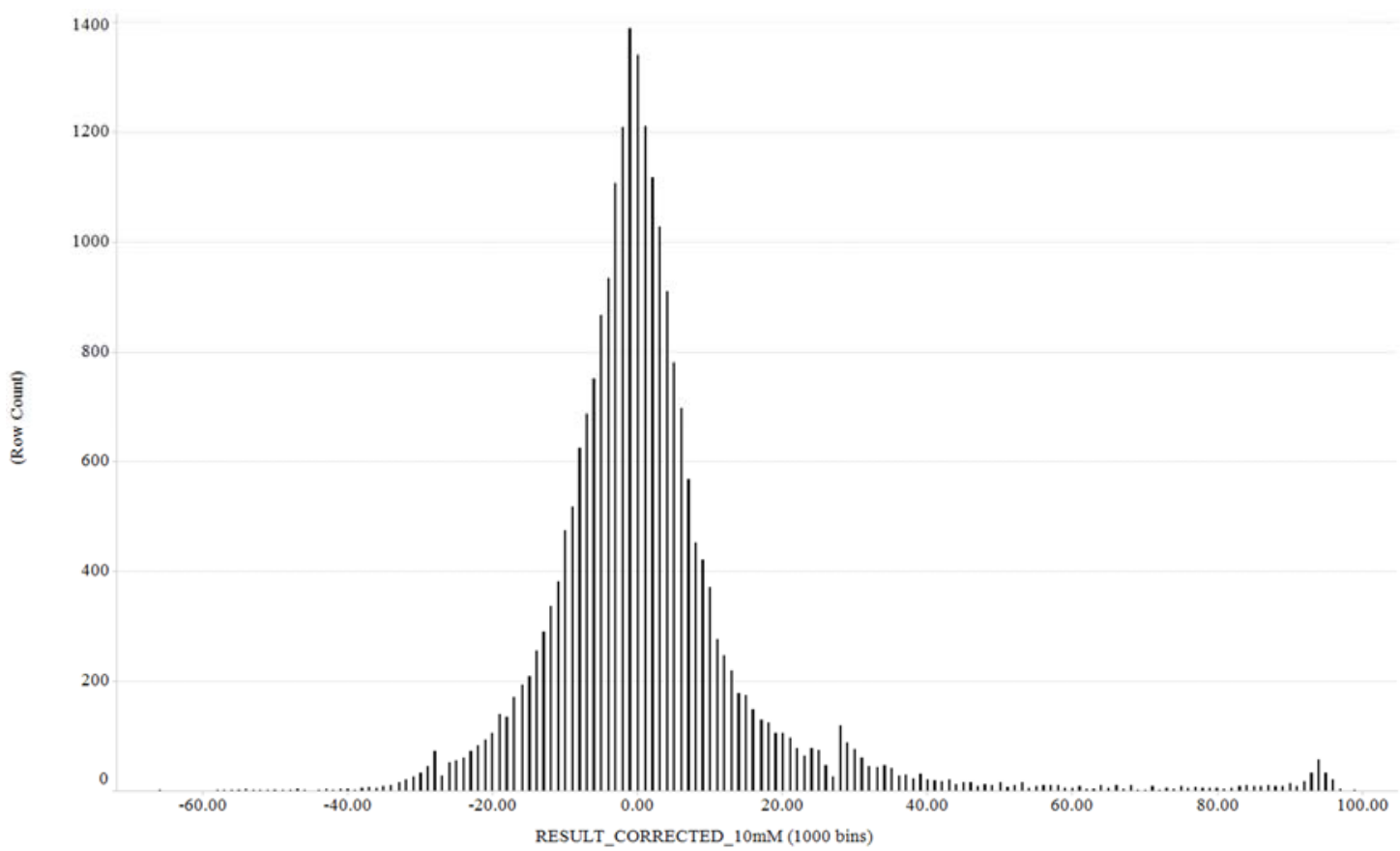

(e) Normalised distribution of USP28 primary screen data. The data is centred around zero. The data was analysed using proprietary AstraZeneca software and TIBCO Spotfire 5.0.1 (TIBCO Software Inc., Boston, MA). 


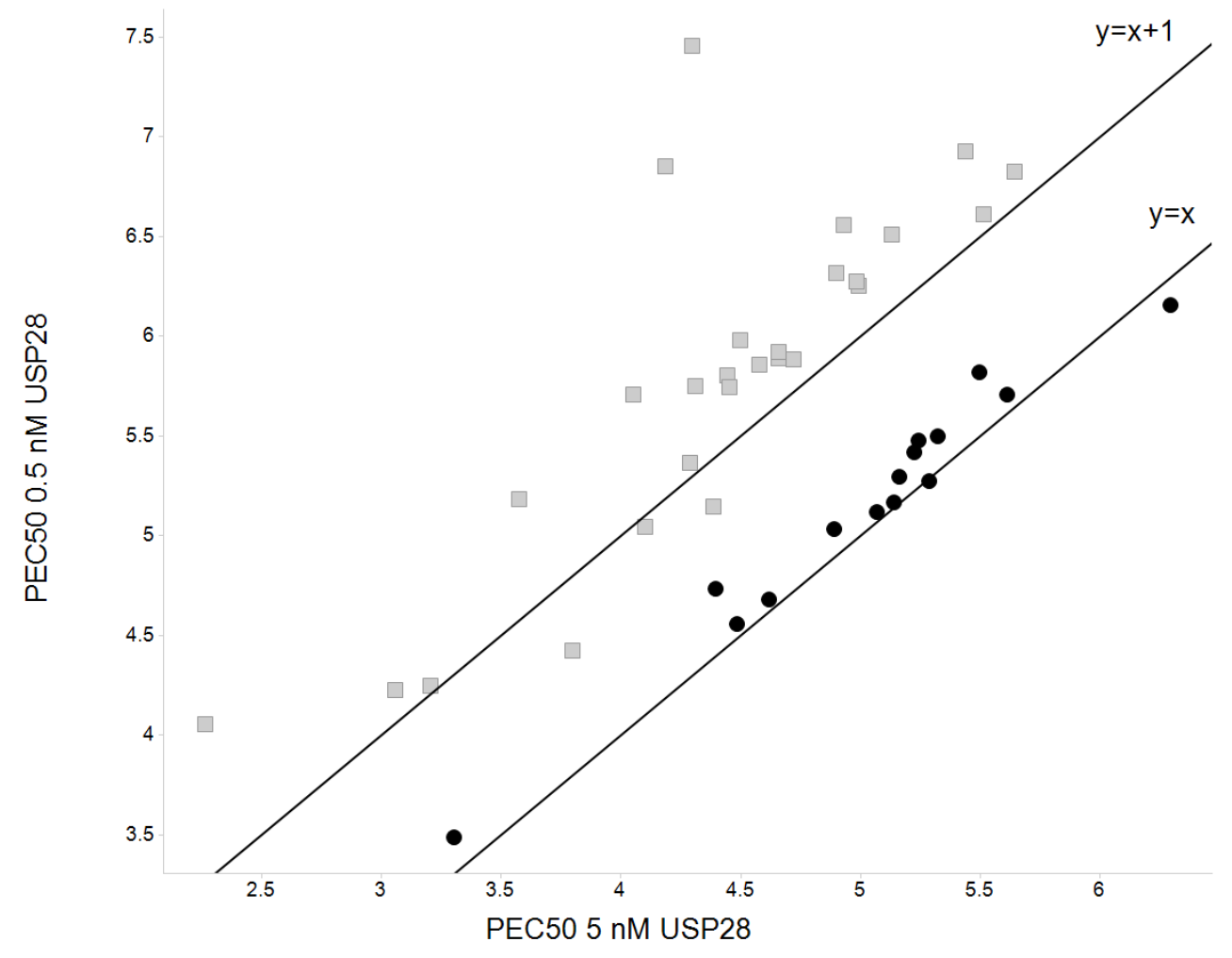

(f) Indication of non-stoichiometric inhibition ("ratio test assay"). The data are the derived pEC50 values determined at $0.5 \mathrm{nM}$ USP28, 30 min incubation (circles) and at $5 \mathrm{nM}$ USP28, $3 \mathrm{~min}$ incubation (squares). The data was analysed using proprietary AstraZeneca software and TIBCO Spotfire 5.0.1 (TIBCO Software Inc., Boston, MA). 
Compound AZ1, $\mathrm{K}_{\mathrm{d}}=3.7 \mu \mathrm{M} \pm 1.2 \mu \mathrm{M}$

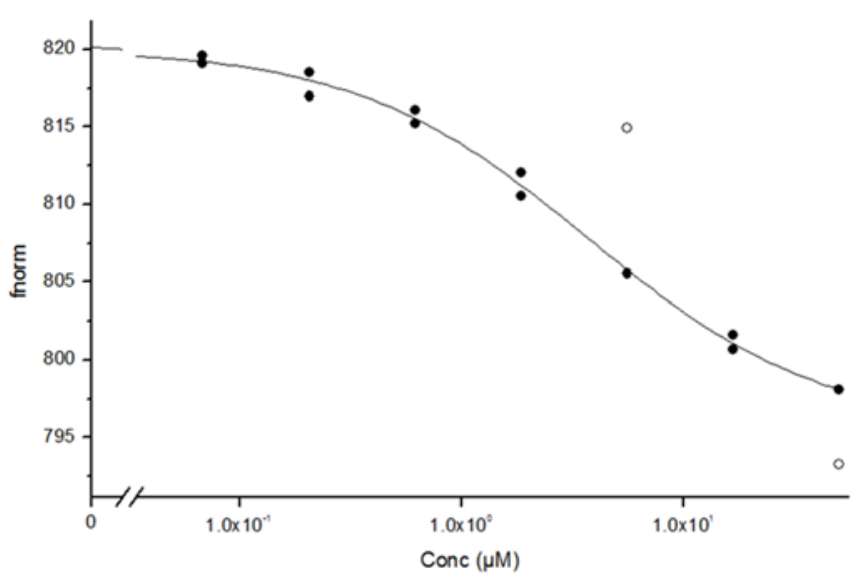

(a) Microscale Thermophoresis: AZ1

Compound AZ2, $\mathrm{K}_{\mathrm{d}}=10.3 \mu \mathrm{M} \pm 4 \mu \mathrm{M}$

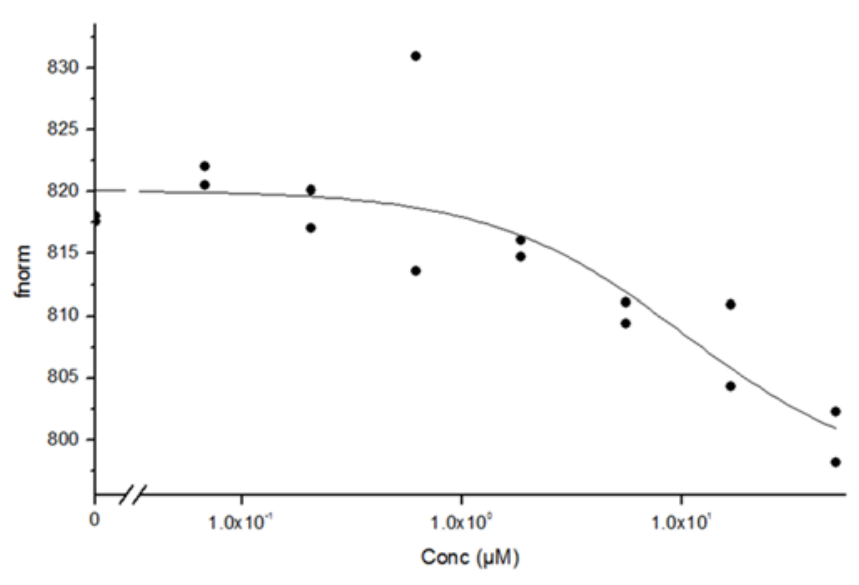

(b) Microscale Thermophoresis: AZ2

Figure S2: Confirmation of USP28 binding by Microscale

Thermophoresis (MST). Kd values were determined utilising the intrinsic fluorescence of USP28 with a 30 minutes incubation with compound for (a) AZ1 and (b) AZ2. The data presented represent two replicates within an experiment, generated on two separate experimental occasions. The data were analysed using Origin software (OriginLab Corporation, Northampton, MA, USA). 
(a) SW480

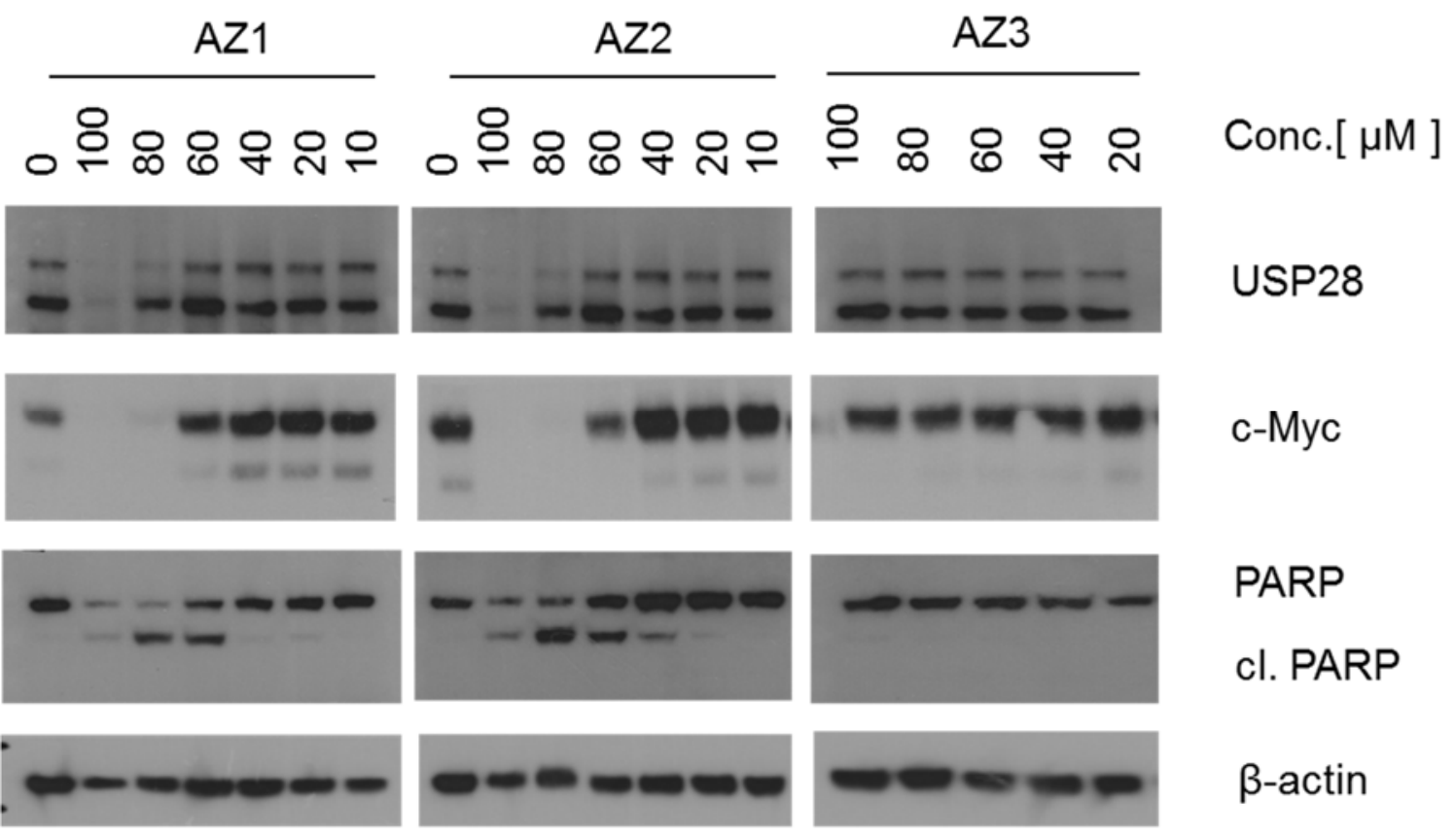

b) HT29

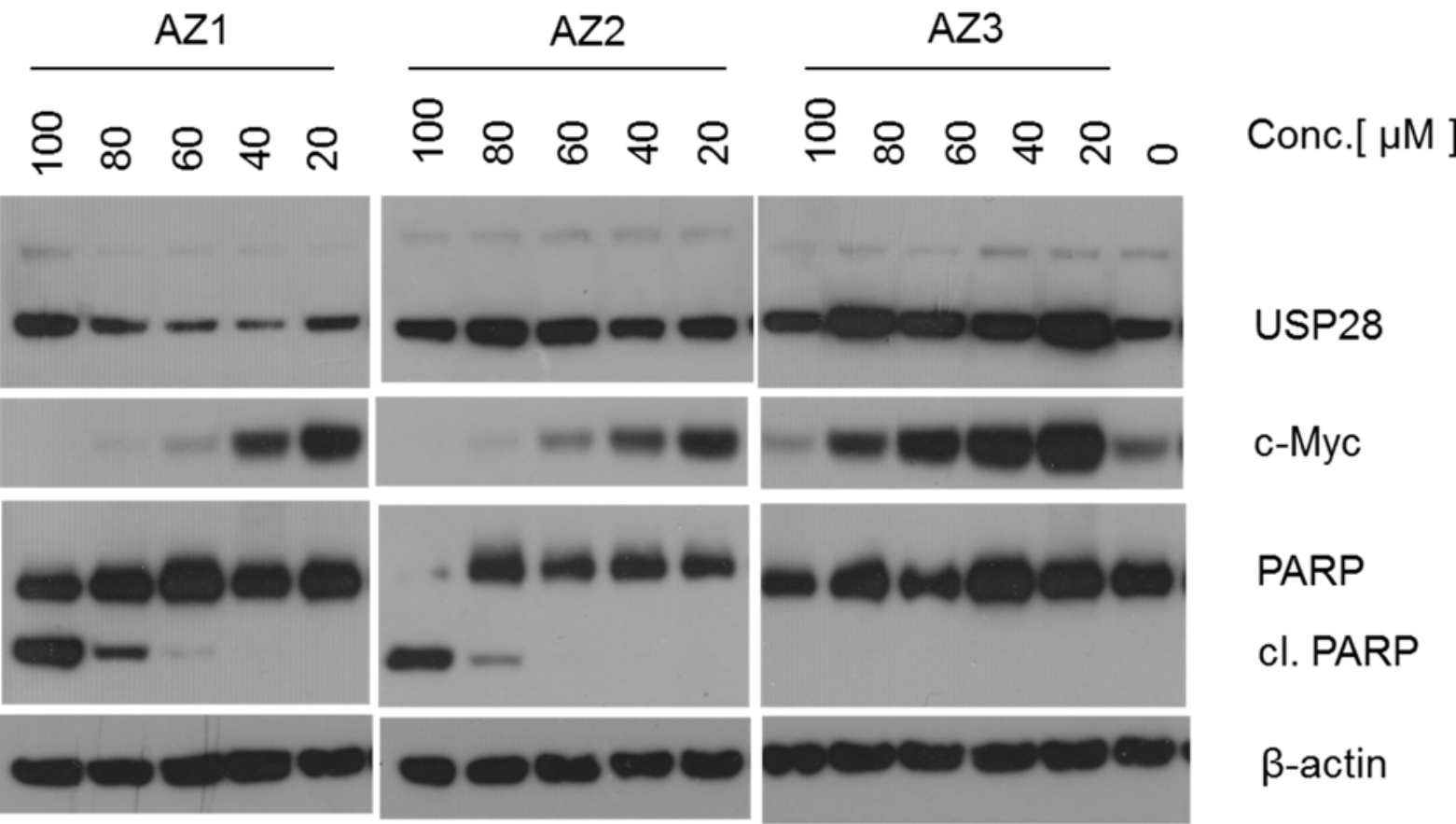


Figure S3 - Modulation of c-Myc levels and apoptosis induction in multiple other cell lines. (a) SW480, (b) HT29 cells were treated with compounds (as indicated) and samples collected after $3 \mathrm{hrs}$ for Western blot analysis probing for USP28, c-Myc and PARP. $\beta$-actin was included as loading control. Full-length PARP (116 kDa), cleaved PARP (cl. PARP, $85 \mathrm{kDa})$. These data are representative data from at least 2 independent experiments. 

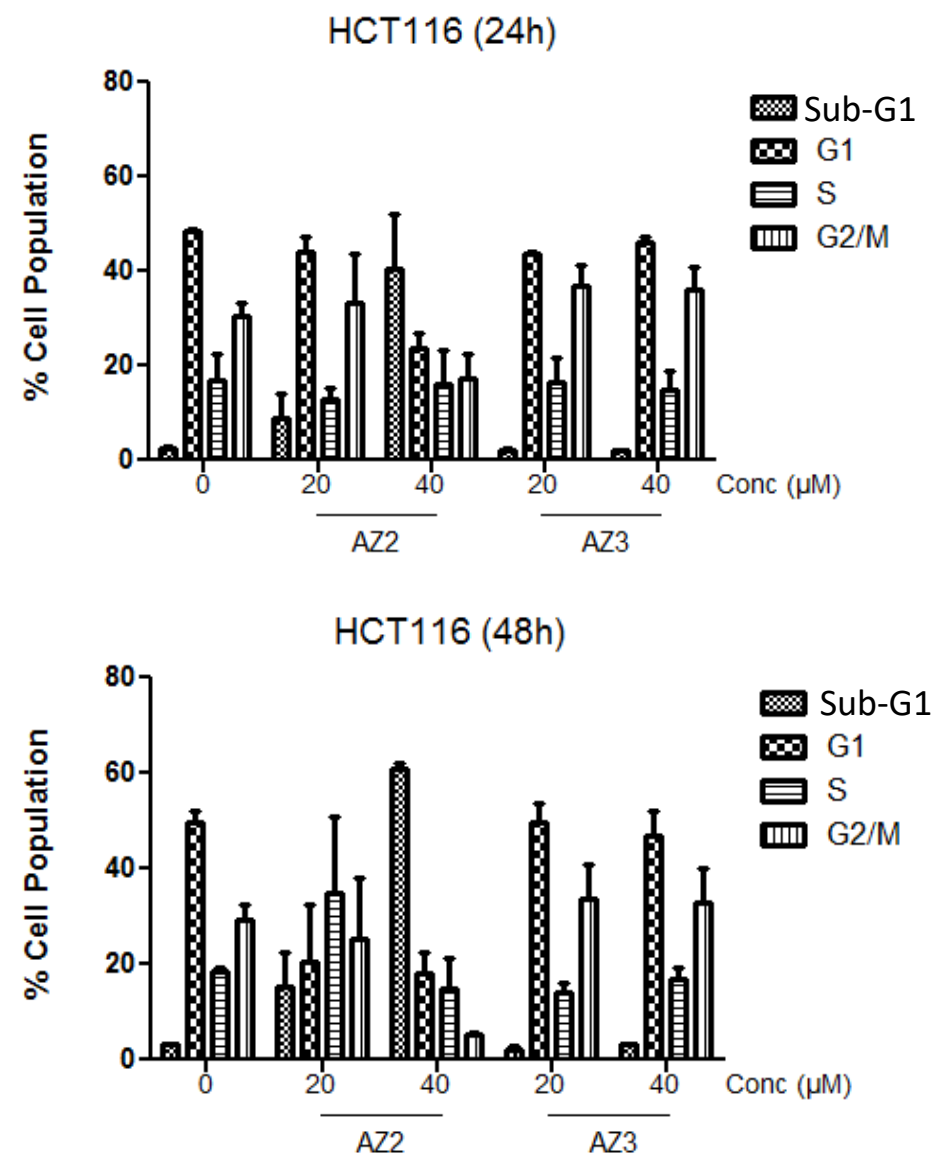

Figure S4: Cell Cycle Analysis of compound treated cells: HCT116 cells were treated with compounds (as indicated), stained with PI and analysed by flow cytometry after 24 and $48 \mathrm{hrs}$ (as indicated). Cell death is evidenced by the accumulation of a sub-G1 population. Data presented as mean of at least three independent experiments. The histogram representations were derived using GraphPadPrism (GraphPad Software, Inc, La Jolla, CA). 


\begin{tabular}{|c|c|c|c|c|}
\hline \multirow[b]{2}{*}{ Cell Lines } & \multirow[b]{2}{*}{ Origin } & \multicolumn{3}{|c|}{$\mathrm{EC}_{50}(\mu \mathrm{M})$} \\
\hline & & AZ1 & AZ2 & AZ3 \\
\hline HCT116 & Colon & 20.1 & 18.7 & 93.2 \\
\hline HT29 & Colon & 18 & 17.2 & 82.1 \\
\hline PC3 & Prostate & 22.5 & 23.3 & $>100$ \\
\hline DU145 & Prostate & 23 & 26.2 & $>100$ \\
\hline LNCap & Prostate & 23.4 & 22 & $>100$ \\
\hline T47D & Breast & 15.9 & 16.4 & 97 \\
\hline U251 & Glioblastoma & 24.6 & 26.1 & 99.8 \\
\hline A2780 & Ovarian & 15.3 & 15.5 & 58.3 \\
\hline A431 & Skin & 25.2 & 28 & $>100$ \\
\hline U937 & Leukemia & 9.8 & 11 & 50 \\
\hline A549 & Lung & 33.5 & 34.8 & $>100$ \\
\hline HMEC-1 & Micro vascular (normal) & 32.5 & 30.8 & $>100$ \\
\hline PANC1 & Pancreatic carcinoma & 19 & 21 & 87 \\
\hline SKOV3 & Ovarian carcinoma & 22 & 20 & 78 \\
\hline U87MG & Glioblastoma & 16.5 & 16.5 & 73 \\
\hline $\mathrm{U} 251$ & Glioblastoma & 17 & 19 & 64 \\
\hline InMyoFib & Human intestinal myofibroblast & 20 & 21 & 91 \\
\hline SW480 & Corolectal adenocarcinoma & 20 & 24 & 102 \\
\hline PANC1 & Pancreatic carcinoma & 19 & 21 & 87 \\
\hline FR2 & Breast epithelial & 32 & 33 & 119 \\
\hline T47D & Breast ductal carcinoma & 17 & $15 . .5$ & 104 \\
\hline MCF7 & Breast adenocarcinoma & 16 & 19 & 63.5 \\
\hline MDA231 & Breast adenocarcinoma & 21 & 24 & 80 \\
\hline $\mathrm{HeLa}$ & Cervix adenocarcinoma & 19 & 22 & 66 \\
\hline NHFL & Norma human lung fibroblasts & 21 & 35 & 111 \\
\hline Hs888LU & Norma human lung epithelial & 25 & 30 & 77 \\
\hline $\mathrm{H} 460$ & Lung carcinoma & 26 & 24 & 70 \\
\hline HFFF2 & Human fetal foreskin & 30 & 29 & 117 \\
\hline PNT2 & Prostate (normal) & 14.3 & 15.5 & 67.6 \\
\hline
\end{tabular}

\section{Supplementary Table 1 - Anti-proliferative activity of AZ1-3 against a range of} cancer cell lines and tissue-matched normal cell lines. Cells were treated with compounds $(0-100 \mu \mathrm{M})$ for $72 \mathrm{hr}$ and viability assessment using the CellTiter-Glo assay (Promega). EC50 values were derived using GraphPad Prism (GraphPad Software, Inc, La Jolla, CA) from at least two independent experiments. 


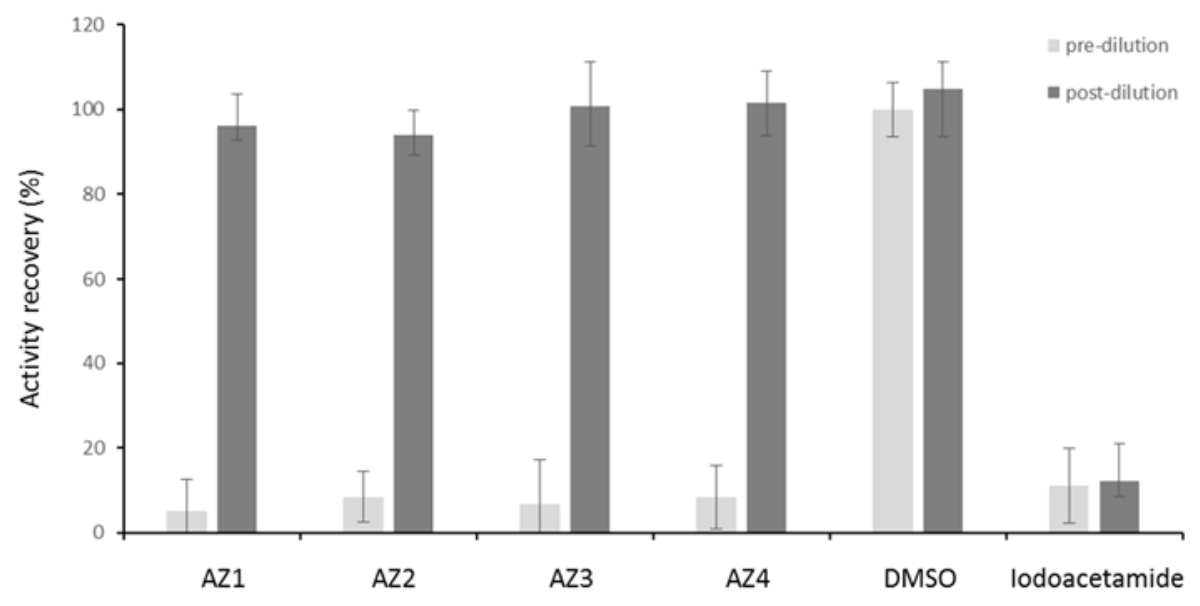

Figure S5: Reversible binding of AZ1-4 was demonstrated by high-dilution assay. USP28 was pre-incubated with $10 \mathrm{x} \mathrm{IC}_{50}$ of the inhibitor or controls (based on Table 1) for 30 min followed by 100x dilution of the samples. Biochemical activity was monitored after $15 \mathrm{~min}$ (as described previously). Activity recovery is indicative of reversible binding following inhibitor re-equilibration. Iodoacetamide was included as a positive assay control acting as a non-specific covalent, irreversible inhibitor (cysteine alkylator). DMSO: no compound control using the same DMSO final concentration for AZ1-4. Data reported as the mean of at least 3 independent experiments with standard deviations. 


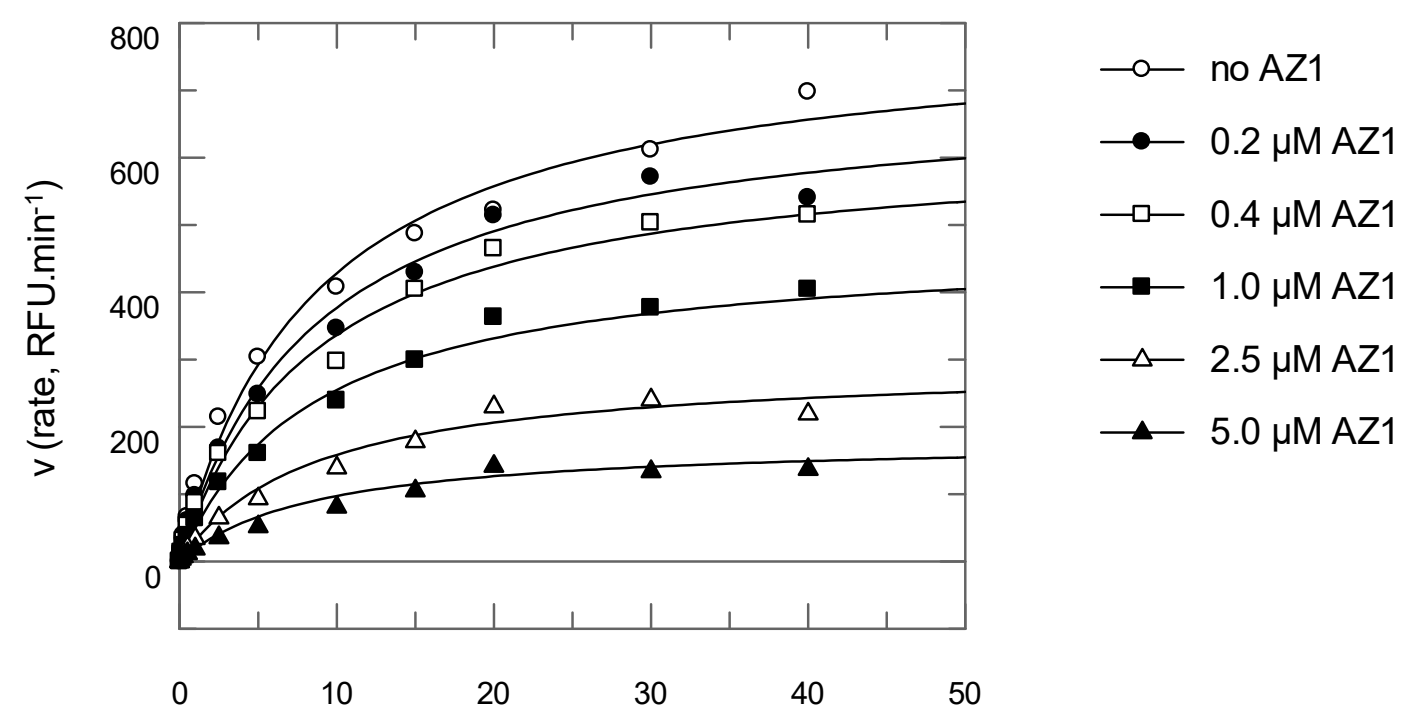

Substrate concentration $(\mu \mathrm{M})$

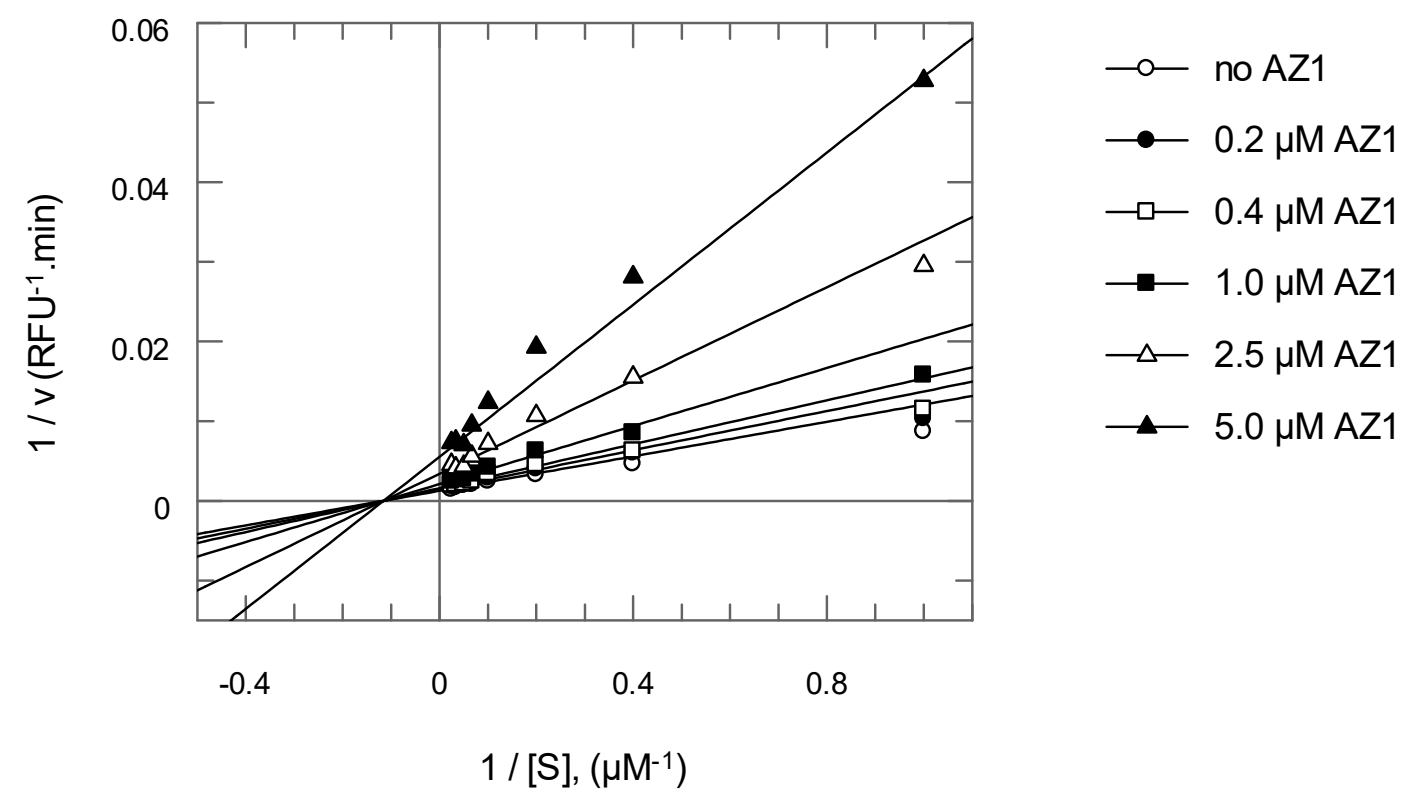

Figure S6: Characterisation of the mode of inhibition of USP28 by AZ1. a, Representative Michaelis-Menten plot. Inhibition was performed as indicated using varying concentrations of Tetra-Ub (from 0 to $40 \mu \mathrm{M}$ ) and inhibitor concentration (from 0 to $5.0 \mu \mathrm{M}$, as indicated). R-square values for fitting were $>0.95$ in all cases. $b$, Lineweaver-Burk plot (plotted using data from $A$ ). 


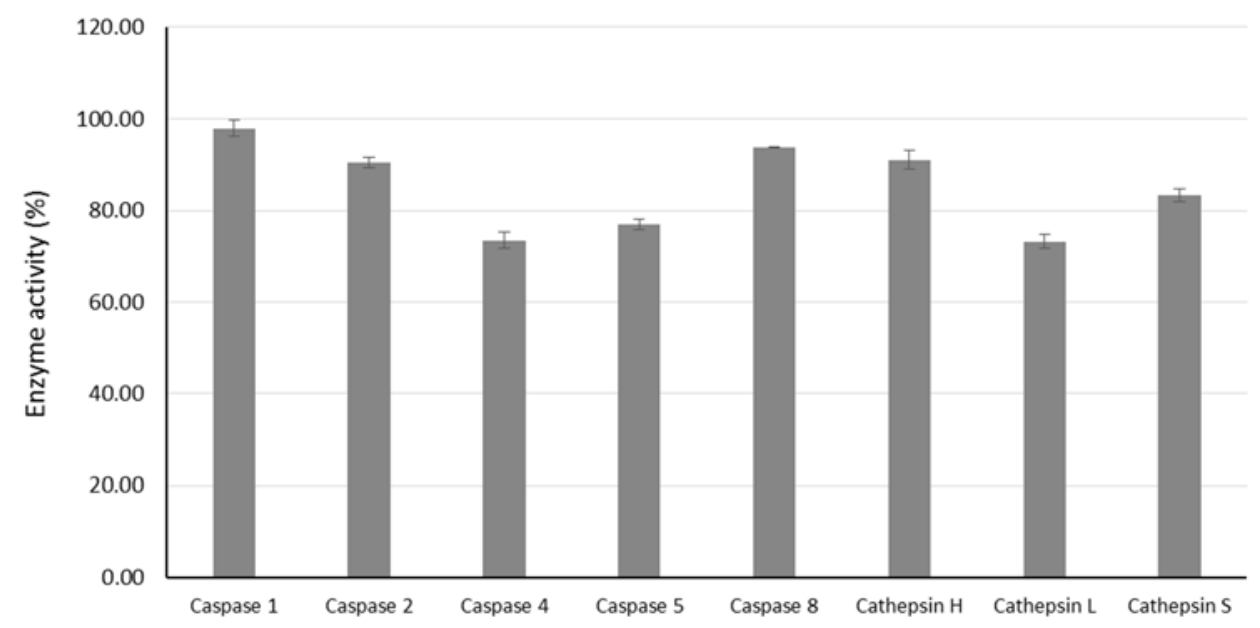

Figure S7: Selectivity profile against a panel of cysteine proteases. Representative selectivity profile of AZ1 against a panel of representative caspases and cathepsins (as indicated). AZ1 was screened at a fixed concentration of $30 \mu \mathrm{M}$. Data was normalised to DMSO control and reported as the mean of 2 independent experiments with standard deviations. 